Florida International University

FIU Digital Commons

FIU Electronic Theses and Dissertations

University Graduate School

$11-15-2006$

\title{
Patterns in belowground primary productivity and belowground biomass in marshes of the Everglades' oligohaline ecotone
}

Gregory M. Juszli

Florida International University

DOI: $10.25148 /$ etd.FI15102110

Follow this and additional works at: https://digitalcommons.fiu.edu/etd

Part of the Biology Commons

\section{Recommended Citation}

Juszli, Gregory M., "Patterns in belowground primary productivity and belowground biomass in marshes of the Everglades' oligohaline ecotone" (2006). FIU Electronic Theses and Dissertations. 2493.

https://digitalcommons.fiu.edu/etd/2493

This work is brought to you for free and open access by the University Graduate School at FIU Digital Commons. It has been accepted for inclusion in FIU Electronic Theses and Dissertations by an authorized administrator of FIU Digital Commons. For more information, please contact dcc@fiu.edu. 


\title{
FLORIDA INTERNATIONAL UNIVERSITY
}

Miami, Florida

\section{PATTERNS IN BELOWGROUND PRIMARY PRODUCTIVITY AND BELOWGROUND BIOMASS IN MARSHES OF THE EVERGLADES' OLIGOHALINE ECOTONE}

\author{
A thesis submitted in partial fulfillment of the \\ requirements for the degree of \\ MASTER OF SCIENCE \\ in \\ BIOLOGY \\ by \\ Gregory M. Juszli
}

2006 
To: Interim Dean Mark Szuchman College of Arts and Sciences

This thesis, written by Gregory M. Juszli, and entitled Patterns in Belowground Primary Productivity and Belowground Biomass in Marshes of the Everglades' Oligohaline Ecotone, having been approved in respect to style and intellectual content, is referred to you for judgment.

We have read this thesis and recommend that it be approved.

\author{
Carlos Coronado-Molina
}

Jennifer Richards

Daniel L. Childers, Major Professor

Date of Defense: November 15, 2006

The thesis of Gregory M. Juszli is approved.

Interim Dean Mark Szuchman College of Arts and Sciences

Dean George Walker University Graduate School

Florida International University, 2006 


\section{ACKNOWLEDGMENTS}

All this work could not have been completed without the help of everyone associated with FIU's Wetland Ecosystems Lab and the Florida Coastal Everglades LTER project. I would thank all those who assisted me with those long, back-breaking days in the field digging soil cores and seemingly endless evenings sorting roots in the lab: Damon Rondeau, Tim Grahl, Greg Losada, Jeff Wozniak, Tiffany Gann, David Iwaniec, Adam Wood, Sarah Ridgway, Sharon Ewe, Mike Right, and Olga Sanchez. I am also greatly indebted to Colin Saunders for his much needed SAS programming skills and statistical help. Thank you to Jenny Richards and Carlos Coronado-Molina for their invaluable insight and patience to help me better understand sawgrass biomass allocation and ecotone process and function. And lastly I would like to thank Dan Childers, for not only paying my bills for the past three years, but providing me an opportunity to expand my knowledge of wetland ecology and for his "work hard, play hard" mentality. 
ABSTRACT OF THE THESIS

PATTERNS IN BELOWGROUND PRIMARY PRODUCTIVITY AND

BELOWGROUND BIOMASS IN MARSHES OF THE EVERGLADES'

OLIGOHALINE ECOTONE

by

Gregory M. Juszli

Florida International University, 2006

Miami, Florida

Professor Daniel. L. Childers, Major Professor

This study quantified and assessed patterns in belowground primary productivity (BPP) and belowground biomass in Cladium jamaicense marshes of the oligohaline ecotone, a transition zone between the two dominant ecosystems (freshwater marsh and mangrove forest) in the Everglades. A $2 \times 2 \times 2$ factorial design was used with transect (Shark River Slough/Taylor Slough), site (estuarine/freshwater), and season (dry/wet) as factors. BPP and belowground biomass were measured using root ingrowth and soil cores, respectively. Across all sites, BPP was significantly greater in the dry season. BPP peaked in Taylor Slough from April-July, the decrease likely due to oxygen saturation in the soil during marsh dry-down. BPP stayed constant in Shark River Slough, which remained inundated almost year-round. These results indicate that Everglades restoration efforts may negatively impact $C$. jamaicense marshes. Belowground biomass increased with nutrient availability, though the effects of hydroperiod were unclear. Future research should include root decomposition and mortality as they are crucial to understanding belowground processes in Everglades marshes. 


\section{TABLE OF CONTENTS}

CHAPTER

PAGE

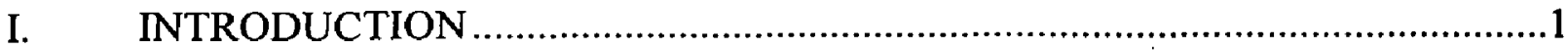

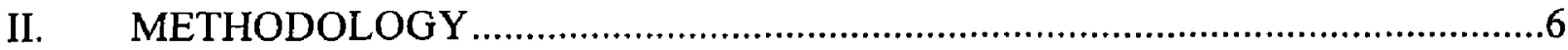

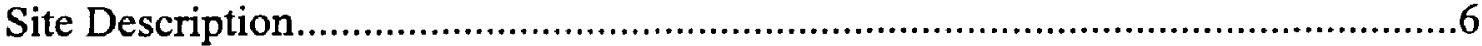

Belowground Standing Stock Biomass .............................................................

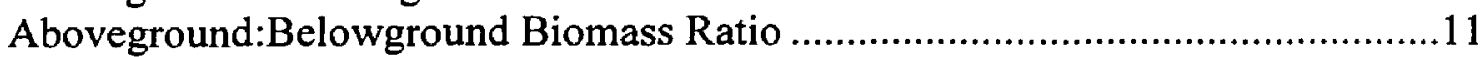

Estimating Belowground Primary Productivity ..............................................12

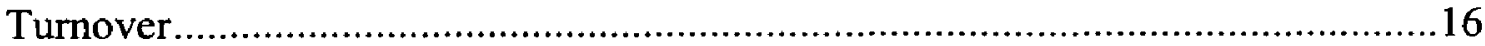

Hydrology and Water/Soil Nutrient Content ................................................16

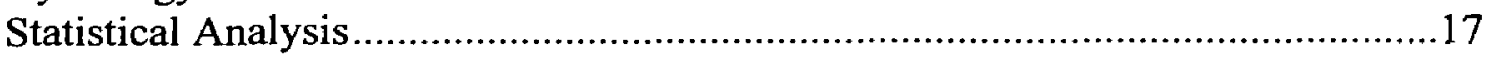

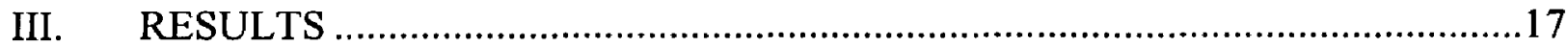

Belowground Standing Stock Biomass............................................................17

Aboveground Standing Stock Biomass ........................................................24

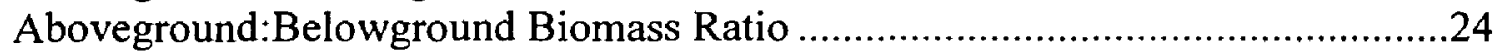

Belowground Primary Productivity .................................................................24

1. Belowground Primary Productivity from 12-Month Ingrowth Cores ...........24

2. Belowground Primary Productivity from 6-Month Ingrowth Cores ..............28

3. Belowground Primary Productivity from 3-Month Ingrowth Cores ..............31

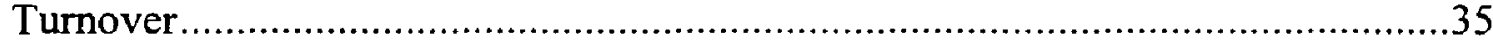

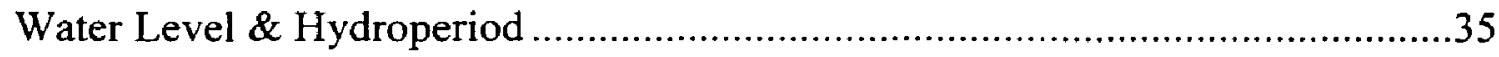

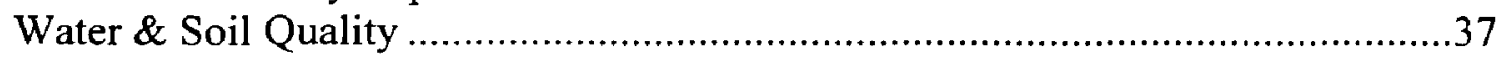

IV. DISCUSSION

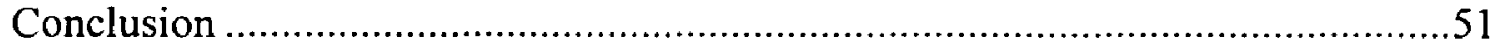

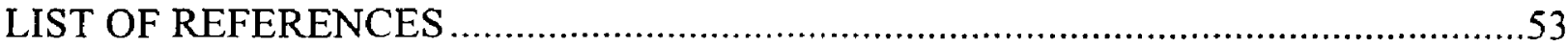




\section{LIST OF TABLES}

TABLE

PAGE

1. General Site Characteristics for the Four Experimental Sampling Sites ....................10

2. Dates of Ingrowth Core and Soil Core Collections ….............................................14

3. Mean P Content of Standing Stock Root, Rhizome, and Shoot Biomass.....................23

4. Mean P Content from Ingrowth Core Root and Rhizomes......................................27

5. Significant Variation in BPP in the 3-Month Ingrowth Cores....................................34 


\section{LIST OF FIGURES}

FIGURE

PAGE

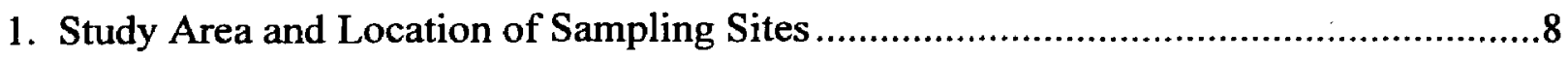

2. Experimental Design Used for the BPP Study at TS-3, SRS-3, and SRS-4.............14

3. Experimental Design Used for the BPP Study at TS-6...................................15

4. Mean Belowground Biomass in January and July (2004) ....................................19

5. Proportion of Root Biomass to Total Belowground Biomass in each $10 \mathrm{~cm}$

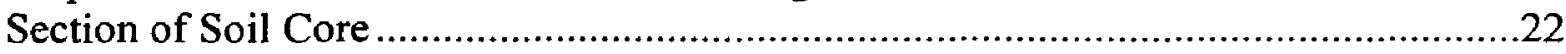

6. Mean Aboveground Biomass in January and July (2004) ...............................23

7. Mean Aboveground:Belowground Biomass Ratios in January and July (2004)........25

8. Mean Annual BPP in Oligohaline Ecotone Marshes ........................................25

9. Mean Seasonal BPP in Oligohaline Ecotone Marshes .........................................30

10. Proportion of Root Productivity to BPP in Each $10 \mathrm{~cm}$ Section of Ingrowth Core......30

11. Mean Seasonal BPP in Oligohaline Ecotone Marshes Over Each 3-Month

Time-step in 2004

12. Comparison of Mean Seasonal Root Productivity Over the 3-month Time-steps for Each $10 \mathrm{~cm}$ Section of Ingrowth Core 36

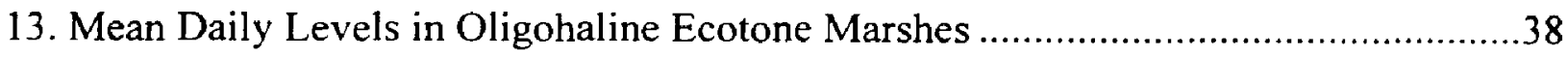

14. Mean Daily Surface Water P Content in Oligohaline Ecotone Marshes ...................38

15. Mean Annual Soil P content in Oligohaline Ecotone Marshes................................39

16. Mean Daily Water Salinity Levels in Oligohaline Ecotone Marshes .........................39 


\section{INTRODUCTION}

Primary production is the accumulation of energy or biomass by primary producers. Similarly primary productivity is the rate at which energy, usually measured in terms of biomass, is accumulated in plants by photosynthetic processes (Ricklefs \& Miller 2000). The main factors that influence primary productivity in wetlands are: nutrient concentrations, water level, hydroperiod, salinity, temperature, and oxygen availability in soils (Miao \& Sklar 1998; Daoust \& Childers 1999; Mitsch \& Gosselink 2000; Lorenzen et al. 2001; Childers et al. 2006). However, the effect of these factors on aboveground primary productivity (ANPP) may be different than their effects on belowground primary productivity (BPP). To understand the effect an environmental factor, such as nutrient availability, has on both ANPP and BPP, a plant's resource allocation needs to be considered.

Resource allocation theory suggests that energy is allocated within a plant such that all resources are concurrently and equally limiting (Tilman 1985, Gleeson \& Tilman 1992). Plants face a resource allocation trade-off, in that they optimize the exploitation of a limiting resource in exchange for a reduction in energy expenditure onto other processes or on acquiring non-limiting resources. To acquire the most limiting resource, plants will allocate more energy, and therefore more biomass, to the structures involved in obtaining that resource. If light is the limiting resource, plants will allocate more of their biomass to aboveground structures. Similarly, plants will allocate more of their biomass to belowground structures if nutrients are more limiting. In nutrient poor soils, plants allocate a larger fraction of their biomass to root structures than do those growing in nutrient rich soils (Chapin 1980) and often exhibit reduced size and growth rate, a 
higher root to shoot ratio, and reduced decomposition (Rubio \& Childers 2006) and turnover rates (Schubauer \& Hopkinson 1984; Vogt et al. 1998; West et al. 2004).

The Florida Everglades is an oligotrophic, phosphorus (P) limited wetland ecosystem with a subtropical climate that has two seasons: wet (June-Nov.) and dry (Dec.-May). Once quite expansive (historically covering over 1 million ha), the remaining Everglades is a compartmentalized system of hydrologic units managed by an intricate network of canals, levees, and water control structures. Approximately $65-70 \%$ of the remaining freshwater Everglades is sawgrass (Cladium jamaicense) marsh, interspersed with wet prairies, tree islands, and deeper-water sloughs (Davis \& Ogden 1994). C. jamaicense has an extremely low nutrient requirement and is the dominant plant species in freshwater Everglades wetlands (Steward \& Ornes 1983). C. jamaicense allocates more biomass to its roots as P concentrations decrease (Miao \& Sklar 1998; Lorenzen et al. 2001; Daoust \& Childers 2004; Brovold unpub.). Hence, the more oligotrophic an Everglades wetland system, the higher the BPP of $C$. jamaicense should be relative to ANPP. Because belowground production is greatly affected by nutrient availability (Vogt et al. 1998), oligotropic Everglades sawgrass marshes are ideal for studying wetland belowground productivity dynamics because a small variation in nutrient availability usually results in visible differences in ANPP and BPP.

ANPP is easily estimated in wetland ecosystems using a number of methods (see Knapp et al. 2006 for a review). None of these approaches, however, apply to estimating BPP. Establishing a universally accepted method for measuring BPP has been a problem, and there is no consensus on how belowground production should be sampled and estimated (Vogt et al. 1998; Hertel \& Leuschner 2002). However. knowledge of BPP is 
crucial to understanding a variety of ecosystem properties, such as soil carbon storage and flux (Scurlock et al. 2002), changing soil environments, and overall ecosystem productivity (Bloomfield et al. 1993), because a sizable proportion of total biomass and production often occurs belowground (Jones et al. 1996). Roots, specifically fine roots, often contribute the largest component to BPP (Nadelhoffer 2000), with only a small portion of annual BPP occurring in rhizomes or subterranean culms (Grier et al. 1981). Researchers have difficulty estimating BPP due to problems visibly monitoring root growth and classifying fine root material as living or dead. These difficulties may be one reason that ANPP studies greatly outnumber belowground studies in the literature. This is especially true for wetland ecosystems, for which very few data on BPP have been published.

Wetlands are some of the most productive ecosystems in the world (Mitsch \& Gosselink 2000). In general, the most productive environments are located at the ecotone of ecosystems (Neilson 1993). An ecotone may be defined as: 1) a habitat created at the boundary of two or more distinctly different ecosystems; 2) an edge of a habitat or ecosystem, or; 3 ) a zone of transition between two ecosystem types (Ricklefs \& Miller 2000). Notably, wetlands have been referred to as biome ecotones (Gosz 1993), in that they are the transitional zones between terrestrial and aquatic ecosystems. Within a biome ecotone, smaller-scale landscape ecotones exist (Gosz 1993), with ecological processes that distinguish them from their adjacent ecosystems (Naiman et al. 1989; Gosz \& Sharpe 1989). Wetland ecotones are metastable (O'Neill et al. 1989), however a change in system state can take place as environmental drivers approach critical threshold levels (Gosz 1993). In the Everglades, there is an expansive landscape ecotone in the southern 
areas of Taylor Slough (TS) and Shark River Slough (SRS), at the interface of freshwater ecosystems (sawgrass marsh and wet prairies) and estuarine ecosystems (mangrove forest). This marine-freshwater interface is the oligohaline estuarine zone. Over the past 50-100 years, rising sea level and decreased freshwater flow caused by anthropogenic hydrologic modifications has resulted in a northerly inland shift (an alteration of system state) of the oligohaline zone (Ross et al. 2000; Gaiser et al. 2006). Therefore, studying primary productivity in this region will enhance our understanding of ecotone dynamics and responses to altered environmental drivers that may ultimately lead to a change in ecosystem state (as evidenced by an oligohaline zone spatial shift or expansion).

The oligohaline estuarine zone often exhibits the area of maximum primary production in estuarine ecosystems (Sharp et al. 1984). Primary production in estuarine ecotones may be enhanced due to dilution of seawater by freshwater inputs, as well as biotic and abiotic processes, such as dissolution of particulates, chemical precipitation, biological assimilation, and mineralization (Mitsch \& Gosselink 2000). The geographic location of the Everglades oligohaline zone, and its corresponding plant communities, is affected primarily by the amount of freshwater entering into the area (Steward \& Ornes 1983). Current and future restoration efforts may allow more freshwater into this wetland ecotone, either shifting it south toward its marine end-member or causing a spatial expansion of the oligohaline zone.

Aboveground NPP in the Florida Everglades has been routinely estimated using plant biomass (Davis, 1989; Daoust \& Childers, 1999; Childers et al. 2006). However, no estimate of ecosystem level primary productivity can be complete without accounting for belowground production. Very few BPP estimates are available for Everglades 
ecosystems, and no such estimates have been documented for the ecotone regions of Taylor and Shark River Sloughs.

In this study, I quantified belowground biomass and BPP at four sites in the oligohaline ecotone of the two main drainage systems of the Florida Everglades: Shark River Slough and Taylor Slough. Salinity in the ecotone is driven mainly by the amount of water released from water management structures. In the wet season, when the water control structures are open or pumping and freshwater is abundant, salinity is negligible in both slough ecotones. However, in the dry season, salinity levels increase with the decreased freshwater inputs from canals and rainfall. Salinity in the Taylor Slough ecotone is seasonally driven, while the Shark River Slough ecotone has both seasonal and tidal salinity pulses (Childers et al. 2006b). Occasional small wind-driven tidal events do occur in Taylor Slough but these are rare (Davis et al. 2004). In these areas, freshwater flowing from canal and rain inputs into the oligohaline zones have very low levels of $\mathrm{P}$ and moderate nitrogen $(\mathrm{N})$ concentrations. In contrast, waters having relatively higher concentrations of $\mathrm{P}$ and less $\mathrm{N}$ enter the oligohaline zones from marine sources (Childers et al. 2006b). In the Taylor Slough ecotone, most $P$ from coastal waters is sequestered by Florida Bay before it reaches the ecotone (Fourqurean et al., 1993), decreasing the $\mathrm{P}$ availability of the nutrient into the region. This $\mathrm{P}$ sequestration does not occur in the Shark River Slough ecotone, because of its direct connectivity to the Gulf of Mexico (Childers et al. 2006b).

I utilized destructive harvesting, soil coring, and ingrowth core techniques to quantify belowground biomass and productivity for $C$. jamaicense, a dominant macrophyte species in the Everglades oligohaline estuarine zone. I had four objectives: 1) 
to estimate and investigate the effects of spatially varying environmental drivers, i.e., $\mathrm{P}$ availability and salinity, on belowground biomass and BPP;2) to estimate and investigate the effects of temporally varying environmental drivers, i.e., hydroperiod and water level, on belowground biomass and $\mathrm{BPP} ; 3)$ to estimate an aboveground:belowground $(\mathrm{A}: \mathrm{B})$ biomass ratio for sawgrass marshes in the ecotone; and 4) to estimate root turnover for $C$. jamaicense in the ecotone area. Based on these objectives, I hypothesized that: A) $C$. jamaicense BPP will be relatively lower in SRS compared to TS due to the increased nutrient availability in SRS; B) C. jamaicense BPP in the estuarine ecotone marshes will be relatively lower than in the freshwater marshes because of the increased salinity in the estuarine areas ; C) C. jamaicense BPP will be relatively higher in the dry season due to the decreased water levels and the possibility of increased oxygen availability in the soil; D) C. jamaicense belowground biomass will be relatively lower in SRS and at the estuarine sites (similar to what was described for BPP), but will not show seasonal variation because of the relatively slow decomposition rates throughout the ecotone (as

per Rubio \& Childers 2006); E) C. jamaicense A:B biomass ratios will be relatively higher in SRS compared to TS due to increased nutrient availability in SRS, and; F) $C$. jamaicense root turnover will be higher in SRS in response to the increased $\mathrm{P}$ availability in the slough.

\section{METHODOLOGY}

\section{Site Description}

All experimental sampling was performed at four pre-established Florida Coastal Everglades Long-term Ecological Research Program (FCE LTER) sampling sites: Two in 
the oligohaline ecotone region of Taylor Slough (TS), TS-3 \& TS-6 and two in the similar region of Shark River Slough (SRS), SRS-3 \& SRS-4, (See Figure 1). These sites were chosen because they delineate the northern and southern boundaries of the ecotone regions for both sloughs, with TS-3 \& SRS-3 representing the northern, freshwaterboundary sites and TS-6 \& SRS-4 the southern, estuarine boundary sites. Hydroperiod in TS varies from about 8 months at TS-3 to nearly 12 months at TS-6. SRS has a hydroperiod that ranges from 9-12 months at each site. C. jamaicense is the dominant vegetation at the two northern sites, with Rhizophora mangle and Eleocharis spp. being the common secondary vegetation. At the southern sites, $R$. mangle is dominant while $C$. jamaicense and Eleocharis spp. comprise the secondary vegetation. Other distinguishing site characteristics are summarized in Table 1.

\section{Belowground Standing Stock Biomass}

Belowground standing stock biomass was measured using standard soil coring techniques. In order to capture seasonal variability, soil cores were collected from each study site in January 2004 and again in July 2004 (Table 2). A sample size of 5 cores per site was used. This sample size derived from the following power analysis: In November 2003, belowground biomass was quantified in 10 soil cores randomly extracted from a 25 $\mathrm{m}^{2}$ C. jamaicense marsh area at TS-3 (for method details see below). From the biomass data, a coefficient of variation (CV) was calculated for each of the 10 possible sample sizes $(n=1-10)$. The standard error was then calculated around the $\mathrm{CV}$ of the maximum replication scenario (10 cores), resulting in the target variation. Five was the minimum number of soil cores that met the target variation, which suggested that sampling five cores at TS-3 would sufficiently capture the spatial heterogeneity in belowground bio- 
Figure 1: Study area of this experiment showing the locations of the four sampling sites, Taylor and Shark River Slough, \& the approximate location of the Everglades oligohaline ecotone.

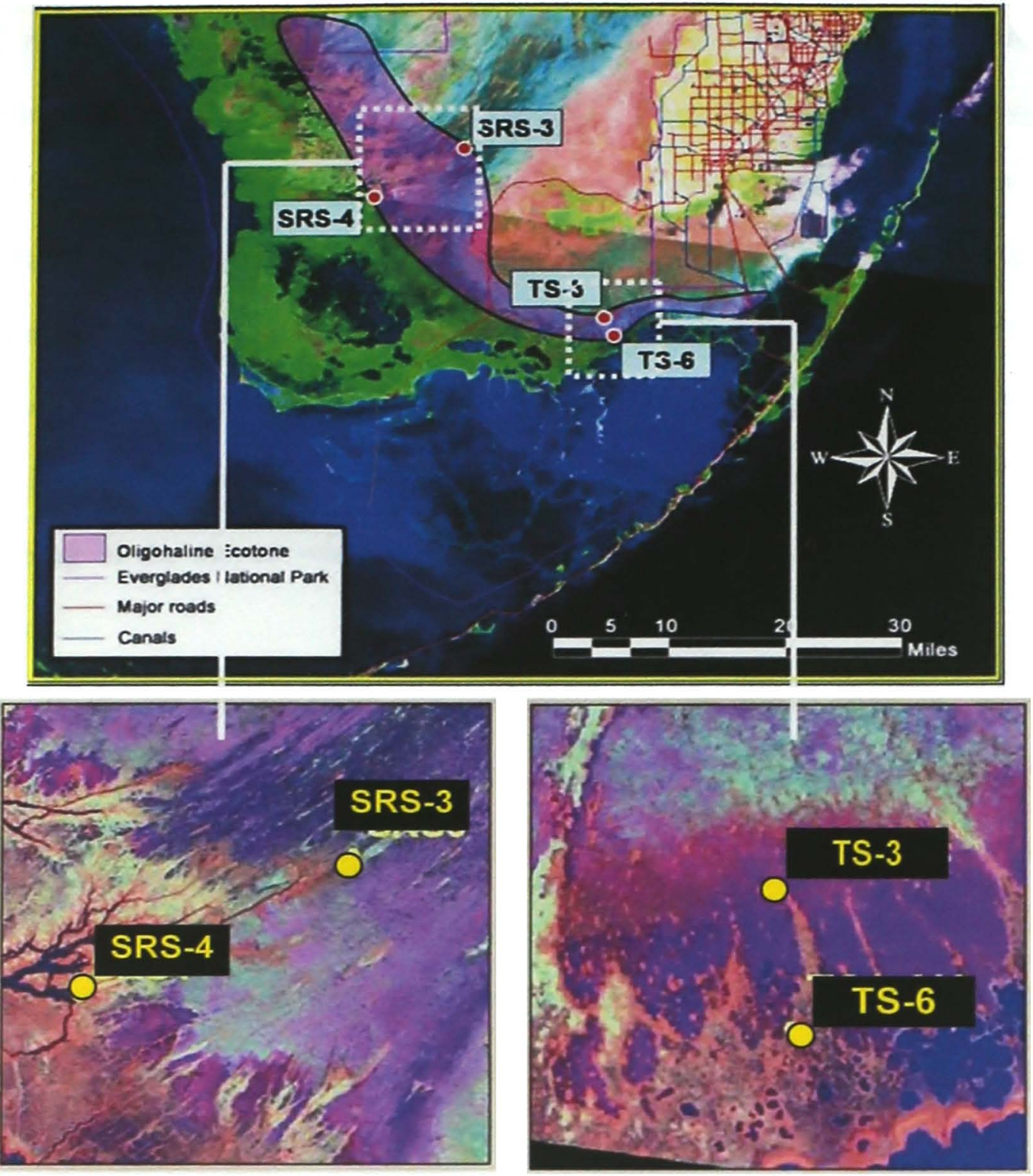

mass across the entire marsh and provide an accurate measure of ecosystem belowground biomass.

After establishing that optimal replication was five cores, soil cores were randomly extracted from each study site by tossing a $15 \mathrm{~cm}$ diameter PVC ring into a 25 
$\mathrm{m}^{2}$ area of $C$. jamaicense marsh. The soil cores were extracted by inserting a $15 \mathrm{~cm}$ diameter PVC pipe with bowsaw-blade edge $30 \mathrm{~cm}$ into the soil directly below where the PVC ring landed. The PVC corer had a screw-top lid, which created suction and allowed fully intact core removal. Because maximum $C$. jamaicense root depths range from 15-30 $\mathrm{cm}$ (Chabbi et al. 2000), soil cores taken to $30 \mathrm{~cm}$ effectively sampled all roots and rhizomes. Upon removal from the ground, each soil core was divided into three $10 \mathrm{~cm}$ sections in order to determine biomass differences along the root profile. Soil and detritus were washed from the roots and rhizomes of all $10 \mathrm{~cm}$ deep root sections using standard $1 \mathrm{~mm}$ brass soil screens. This wet-sieving was carried out in the field. All material remaining in the sieves was then bagged and transported to the lab for separation and analysis.

In the lab, living roots and rhizomes were separated from the necromass (dead roots and unidentifiable organic matter) visually. This visual separation was completed with the aid of a self-created classification key based primarily on root and rhizome color and friability. Dead roots and rhizomes tend to be less elastic, more brittle, and darker in color compared to living roots and rhizomes (Nadelhoffer et al. 1985). In the case where certain roots/rhizomes could not be visually categorized as living or dead, they were considered living. After separating all the living roots and rhizomes in the sample, they were rewashed, dried at $70^{\circ} \mathrm{C}$, and weighed. An average dry mass for each sampling site was calculated from the total dry mass of the five collected cores. In addition, mean dry mass was calculated for the upper, middle, and bottom $10 \mathrm{~cm}$ soil core sections for each site. Root biomass was reported as the mean dry mass divided by the surface per unit area of each soil core. 


\begin{tabular}{|c|c|c|c|c|}
\hline & TS/PH-3 & TSIPH-6 & SRS-3 & SRS-4 \\
\hline Watershed & Taylor Slough & Taylor Slough & Shark River Slough & Shark River Slough \\
\hline Physiography & Flat wetlands & $\begin{array}{l}\text { Flat estuarine } \\
\text { wetlands }\end{array}$ & Flat wotlands & $\begin{array}{l}\text { Flat estuarine } \\
\text { wetlands }\end{array}$ \\
\hline Hydroperiod & About 10 months & About 12 months & $\begin{array}{l}\text { Varying between 9-12 } \\
\text { months }\end{array}$ & $\begin{array}{l}\text { Varying between 9-12 } \\
\text { months } \\
\end{array}$ \\
\hline Hydrography & $\begin{array}{l}\text { Seasonally driven } \\
\text { sheetflow }\end{array}$ & $\begin{array}{l}\text { Seasonatly driven } \\
\text { freshwater inputs and } \\
\text { wind-driven estuarine } \\
\text { inputs }\end{array}$ & $\begin{array}{l}\text { Seasonally driven } \\
\text { sheetflow }\end{array}$ & $\begin{array}{l}\text { Seasonally driven } \\
\text { freshwater inputs and } \\
\text { tidally driven oceanic } \\
\text { inputs }\end{array}$ \\
\hline Topography & Flat & $\begin{array}{l}\text { Flat, with tidal croek } \\
\text { topography }\end{array}$ & $\begin{array}{l}\text { Flat, } w / \text { ridge \& slough } \\
\text { microtopography }\end{array}$ & $\begin{array}{l}\text { Flat, w/ tidal crook } \\
\text { topography }\end{array}$ \\
\hline Geology & Limestone bedrock & Limestone bedrock & Limestone bedrock & Limestone bedrock \\
\hline Soil & $\begin{array}{l}\text { Wetland marly peat, } \\
1 \mathrm{~m} \text { thick } \\
\end{array}$ & $\begin{array}{l}\text { Wotland peat, > 1m } \\
\text { thick }\end{array}$ & Wetland peat, > 1m thick & $\begin{array}{l}\text { Wetland peat, }>1 \mathrm{~m} \\
\text { thick }\end{array}$ \\
\hline Vegetation & $\begin{array}{l}\text { Sparse sawgrass } \\
\text { marsh }\end{array}$ & $\begin{array}{l}\text { Mangrove forest } \\
\text { interspersed w/ } \\
\text { sawgrass stands }\end{array}$ & $\begin{array}{l}\text { Sawgrass dominated } \\
\text { marsh interspersed wl } \\
\text { Eleocharis }\end{array}$ & $\begin{array}{l}\text { Mangrove forest } \\
\text { interspersed w/ } \\
\text { sawgrass stands }\end{array}$ \\
\hline Habitat & Freshwater wetland & $\begin{array}{l}\text { Mangrove wetland, } \\
\text { low/dwarf stature }\end{array}$ & Freshwater wetland & $\begin{array}{l}\text { Mangrove wetland, } \\
\text { low/dwarf stature }\end{array}$ \\
\hline
\end{tabular}

It should be noted that many different root separation techniques were applied to preliminary field samples in order to determine the method that most effectively sorted the belowground $C$. jamaicense material into living or dead. First, two commonly used biological stains, Congo Red and Thionin, were tried. When Congo Red was applied to the $C$. jamaicense roots, the stain was absorbed into the living roots turning them a bright red color. In theory, dead roots do not absorb the stain, however some roots that were clearly dead absorbed the stain and turned a pale red color while others did not. This inconsistency made the Congo Red staining method a poor choice for classifying $C$. jamaicense roots. Roots stained with Thionin were similarly ambiguous: Living roots stained with Thionin turned a purple color, while dead roots turned black. However, the difference between purple and black, and the corresponding living and dead roots, was often difficult to discern under normal magnification and lighting conditions. The additional labor and equipment needed for this biological stain did not result in a more 
accurate biomass estimate than the visual inspection method and therefore dye techniques were not used.

Ludox is also often used to separate living from dead root material. In this method, belowground plant material is placed in a series of two increasingly diluted concentrations of Ludox solution, $10 \%$ and $6 \%$ respectively (Robertson and Dixon 1993). The living roots separate from the necromass by floating to the surface of the solution, while the dead material sinks. Ludox is a colloidal silica solution that, when used on mangroves, effectively separated $94 \%$ of dead roots from living roots (Robertson and Dixon 1993). However, I found that this separation never occurred with my $C$. jamaicense roots. The roots failed to separate despite the concentration of Ludox solution used, the amount of root material added to the Ludox, or the ratio of living to dead roots placed in the solution. I tried a number of varying solution concentrations, but none of these efforts allowed Ludox to be used for viable root classification.

After calculating average belowground biomass, a random subsample of dried root and rhizome biomass from each $10 \mathrm{~cm}$ section of core sample was used to determine total P (P) content. These samples were ground in a Wiley Mill, weighed, and analyzed (Sharp \& Solorzano 1980). P was calculated by multiplying the dry mass per each given site and collection event and the tissue $\mathrm{P}$ concentrations in each corresponding subset sample.

\section{Aboveground:Belowground Biomass Ratio}

Aboveground biomass was also collected with each belowground biomass sampling from all cores in the field (Table 2). As described previously, a $15 \mathrm{~cm}$ diameter PVC ring was randomly positioned on the marsh surface to mark where a soil core would 
be extracted. All $C$. jamaicense culms located within this $15 \mathrm{~cm}$ diameter area were clipped at the base of their meristems (as per the accepted destructive method), bagged, and taken back to the lab. There, live leaves were separated from dead leaves, then dried at $70^{\circ} \mathrm{C}$ and weighed. All dried $C$. jamaicense shoots were then ground in a Wiley mill and analyzed for tissue $\mathbf{P}$ concentrations, as described above. Aboveground biomass at each site was recorded as the average dry shoot mass divided by $0.01824 \mathrm{~m}^{2}$ (the surface area of the $15 \mathrm{~cm}$ ring per unit area). The aboveground biomass was then divided by the belowground biomass, to establish aboveground to belowground biomass ratios for each site.

\section{Estimating Belowground Primary Productivity}

Belowground productivity was estimated using the ingrowth core method (Vogt and Persson 1991). Ingrowth cores were "incubated" for 3 different time intervals to quantify BPP: 3 months, 6 months, and 12 months. These time-steps were selected in order to provide an annual BPP estimate, detect seasonal variability (6-month cores), and identify seasons with significantly high or low BPP (3 month cores). In January 2004, 20 ingrowth bags were randomly deployed in a $4 \mathrm{~m} \times 5 \mathrm{~m}$ grid at TS-3, SRS-3, \& SRS-4 (one bag located in one of twenty $1 \mathrm{~m}^{2}$ plots within each grid, similar arrangement at each site) (Figure 2). This grid design could not be used at TS-6 because of the sparse distribution of $C$. jamaicense at the site. At TS-6, 20 bags were set into four separate smaller marsh patches of varying size which had a total area of $20 \mathrm{~m}^{2}$ (Figure 3). At all sites, five $1 \mathrm{~m}^{2}$ plots were allocated to 3 -month ingrowth bags, five $1 \mathrm{~m}^{2}$ plots given to 6 -month ingrowth bags, five to 12-month bags, and the final five were designated as back-up locations, which would be used if any of the other bags were lost or damaged. The 3 and 6 -month 
ingrowth bags were collected and replaced after each respective time interval, with final retrieval of all bags in January 2005 to complete the experiment at each site (Table 2).

To measure root ingrowth, soil cores were extracted as described previously and each replaced with an individual mesh bag filled with a mix of commercially available sphagnum moss and humus peat. The nylon mesh bag was sewn to be approximately 30 $\mathrm{cm}$ long and measure approximately $15 \mathrm{~cm}$ in diameter, with a $5 \mathrm{~mm}$ mesh size. The bags were sewn closed at their bottom and were open at the top. Upon core extraction, the mesh bags were placed into the void. At the end of each sampling interval, the bags were retrieved by cutting the bag away from the surrounding soil, carefully including all roots/rhizomes that had grown into the bag. Once this was completed, the bags were cut into three equal $10 \mathrm{~cm}$ long sections. The content of each bag section was washed in the field. The roots/rhizomes were then bagged and taken back to the lab for separation as live or dead using the same visual inspection method as described previously. This separation procedure involved differentiating $C$. jamaicense roots from other pre-existing roots found within the humus peat/sphagnum moss substrate. All living material was dried at $70^{\circ} \mathrm{C}$ and weighed. The dry mass from each sample was divided by the surface area of the soil core to obtain a biomass. BPP is defined as the subsequent growth of roots/rhizomes into each ingrowth core (as measured by the accumulated biomass) during each time-step (3-months, 6-months, or 12-months) (Vogt and Persson, 1991). The mean of the five 12-month biomass samples was calculated to provide the average annual BPP at each site (expressed as gdw $/ \mathrm{m}^{2} / \mathrm{yr}$ ). Average monthly estimates of BPP were obtained from the 3-month and 6-month biomass samples (expressed as $\mathrm{gdw} / \mathrm{m}^{2} / \mathrm{mo}$ ) by dividing the respective samples by 3 or 6 , then taking the average from each site and "incubation" 
Table 2: The collection dates of all ingrowth bags, belowground standing stock biomass soil cores and aboveground destructive sampling events at each ecotone site. The experiment ran for one year, beginning in January 2004 and ending in January 2005.

\begin{tabular}{|l|c|c|c|l|c|}
\hline Collection Type & January & April & July & October & January '05 \\
\hline Soil Core & $\mathrm{X}$ & & $\mathrm{X}$ & & \\
\hline Aboveground & $\mathrm{X}$ & & $\mathrm{X}$ & & \\
\hline 3-month Ingrowth Bag & & $\mathrm{X}$ & $\mathrm{X}$ & $\mathrm{X}$ & $\mathrm{X}$ \\
\hline 6-month Ingrowth Bag & & & $\mathrm{X}$ & & $\mathrm{X}$ \\
\hline 12-month Ingrowth Bag & & & & & X \\
\hline
\end{tabular}

Figure 2: Diagram of the experimental design used at TS-3, SRS-3 \& SRS-4 for the BPP component of this study. Circles with the number " 3 " indicate the locations of the 3 month ingrowth bags within the grid; circles with the number "6" show the placements of the 6-month ingrowth bags; circles with the number "12", the 12-month ingrowth bags; and circles with the letter " $\mathrm{B}$ " exhibit the locations of all back-up bags.

TS-3, SRS-3 \& SRS-4

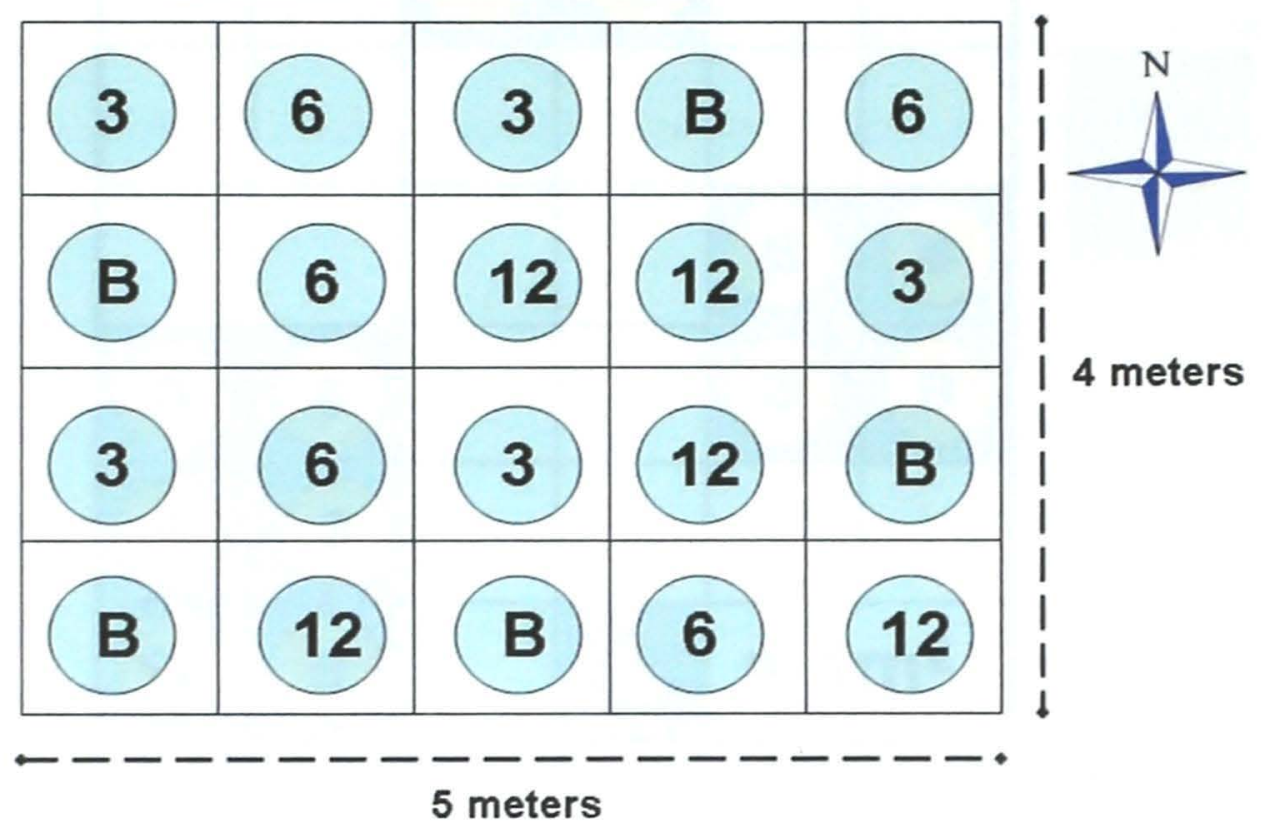


Figure 3: Diagram of the experimental design used at TS-6. The design at TS-6 differs from that of the other sites because $C$. jamaicense stands were typically not large enough to support a $4 \times 5 \mathrm{~m}$ grid at the site. Again, circles with the number " 3 " indicate the locations of the 3-month ingrowth bags within the grid; circles with the number "6" show the placements of the 6-month ingrowth bags; circles with the number "12", the 12month ingrowth bags; and circles with the letter " $\mathrm{B}$ " exhibit the locations of all back-up bags. The dark squares represent $1 \mathrm{~m}^{2}$ of $C$. jamaicense marsh, and the white squares represent $1 \mathrm{~m}^{2}$ of either mangrove or aquatic habitat.

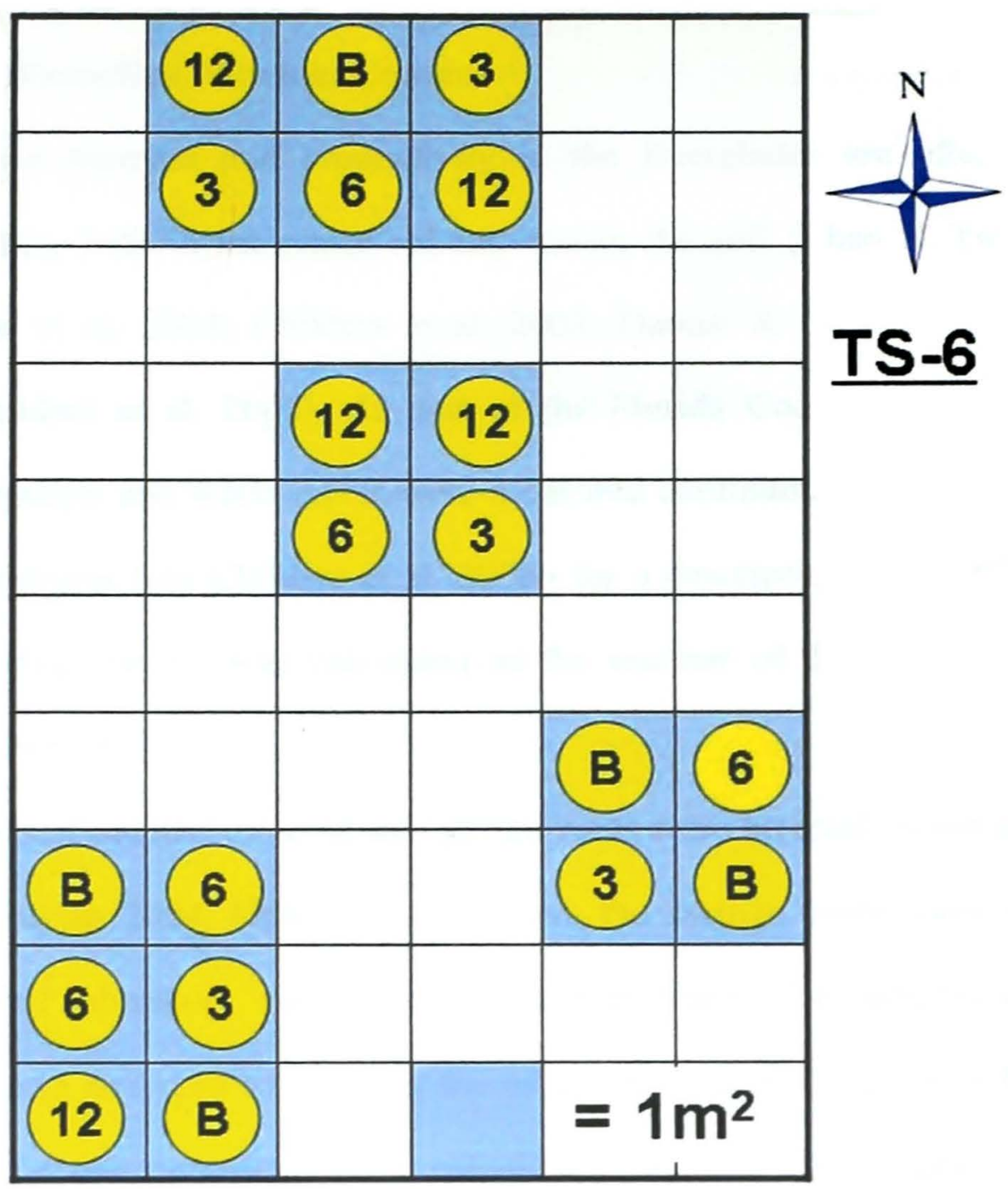

period. Means were calculated from the entire ingrowth core and from each $10 \mathrm{~cm}$ core section. A subset of dried C. jamaicense roots and rhizomes taken from each ingrowth 
core was then ground in a Wiley mill and analyzed for their tissue $\mathrm{P}$ content, as described previously.

\section{Turnover}

Root and rhizome turnover were estimated by taking the mean annual BPP value per site and dividing it by the mean standing stock biomass value from the two seasonal sampling events at each site (Annual BPP / Biomass). Turnover is expressed per year.

\section{Hydrology and Water/Soil Nutrient Content}

Macrophyte biomass and productivity in the Everglades are often related to nutrient availability, both in the water column and in the soil (Chen \& Twilley 1999; Coronado-Molina et al. 2004; Childers et al. 2003; Daoust \& Childers 2004), and to water depth (Childers et al. 2006). As part of the Florida Coastal Everglades LTER program, water quality and water levels were measured continuously at each of the four sites in this experiment (see Childers et al. 2006b for a description of the water quality methods used). Hydroperiod was calculated as the number of days the average daily water level was above 0 .

To assess soil quality, three $60 \mathrm{ml}$ syringe cores were inserted $10 \mathrm{~cm}$ into the soil at each site in August 2004. Upon soil extraction, the syringe cores were capped and stored on ice until laboratory analysis could be performed. The samples were dried, weighed, ashed, and analyzed for P using the ascorbate method (Chambers \& Pederson 2006). Phosphorus concentrations were calculated per unit dry weight of soil, and converted to bulk $\mathrm{P}$ content per unit area by normalizing to soil bulk density. Bulk density was calculated by dividing the dry mass of each sample into the known volume of each syringe core. 


\section{Statistical Analysis}

A priori statistical analyses were conducted to ensure normality, independence, and equal variance in the distribution of the data, allowing the use of parametric tests. A $2 \times 2 \times 2$ factorial ANOVA design was used for this experiment. The factors were transect $(n=2)$, ecotone site (freshwater or estuarine; $n=2$ ), and season $(n=2)$. The only exception to this design was in the 12 -month BPP experiment, which used a $2 \times 2$ factorial design because there were no seasonal samples. All analyses were conducted using SAS version 9.1 (SAS Institute Inc 1989), with all results significant at $\alpha=0.05$, unless otherwise stated. All data were analyzed using one way ANOVA, with the exception of the 3-month BPP data, which were interpreted using repeated measures ANOVA. Repeated measures was chosen because the ingrowth bags were being replaced into the same location after each 3-month incubation period. Post-hoc comparisons were made using Tukey's HSD (Zar 1996). A stepwise regression was performed on the belowground biomass data to determine which, if any, of the measured environmental parameters (water level, hydroperiod, salinity, water column $\mathrm{P}$, and water column N) most-affected belowground biomass.

\section{RESULTS}

\section{Belowground Standing Stock Biomass}

C. jamaicense marshes of the oligohaline ecotone showed seasonal and spatial patterns in belowground biomass. Belowground biomass ranged from $420 \mathrm{gdw} / \mathrm{m}^{2}$ in July at TS-6 to $1963 \mathrm{gdw} / \mathrm{m}^{2}$ at SRS-4 in January (Figure 4) with an average of $1038 \mathrm{gdw} / \mathrm{m}^{2}$ across all sites. The SRS sites had significantly higher values $\left(F_{1.33}=12.89, P=0.002\right)$ 
compared with TS. The data also showed significantly more biomass $\left(F_{1,33}=14.52\right.$, $\mathrm{P}=0.001$ ) in the January sampling event compared to the July sampling. Belowground biomass was similar between the estuarine and freshwater sites. There was a significant interaction of site and sampling event $\left(\mathrm{F}_{1,33}=5.47 ; \mathrm{P}=0.032\right)$. Belowground biomass in January at SRS-4 \& TS-6 was significantly higher than in July. The same was true for the freshwater sites, but the difference in belowground biomass between sampling events was not as great (Figure 4).

Across all sites, roots comprised $47 \%$ of the belowground biomass ( $486 \mathrm{gdw} / \mathrm{m}^{2}$ ) (rhizome biomass $=553 \mathrm{gdw} / \mathrm{m}^{2}$ ). This nearly equal proportion of mean rhizome to root biomass was not seen at all sites. In fact, the four sites exhibited considerable variability in root-rhizome partitioning of total belowground biomass (Figure 4). In the January SRS-3 belowground biomass sampling, roots accounted for $39 \%$ of the total belowground biomass. This percentage was unchanged in the July sampling. TS-6 showed a similar trend in that the proportion of roots and rhizomes that comprise total belowground biomass did not change over the two sampling events. Roots accounted for $55 \%$ and $57 \%$ of the total belowground biomass in the January and July samplings, respectively. SRS-4 and TS-3 showed substantial variation in root-rhizome ratios between the two sampling events, with roots greatly increasing their proportion of total belowground biomass. The proportion of root biomass increased from $44 \%$ to $71 \%$ of the total belowground biomass from January to July at SRS-4. TS-3 showed a similar trend, though not as dramatic, with the proportion of root biomass increasing from $28 \%$ to $46 \%$, between January and July.

SRS had significantly higher root biomass than $T S\left(F_{1,33}=12.07, P=0.003\right)$ and the estuarine ecotone sites exhibited significantly higher $\left(\mathrm{F}_{1,33}=16.55, \mathrm{P}=0.001\right)$ root biomass 
Figure 4: Mean $C$. jamaicense belowground biomass at each sampling site in the January (A) and July (B) sampling events of 2004. Roots and rhizomes contribute different proportions of biomass to the total belowground biomass at each site in the oligohaline ecotone marshes.

\section{A) January Sampling}

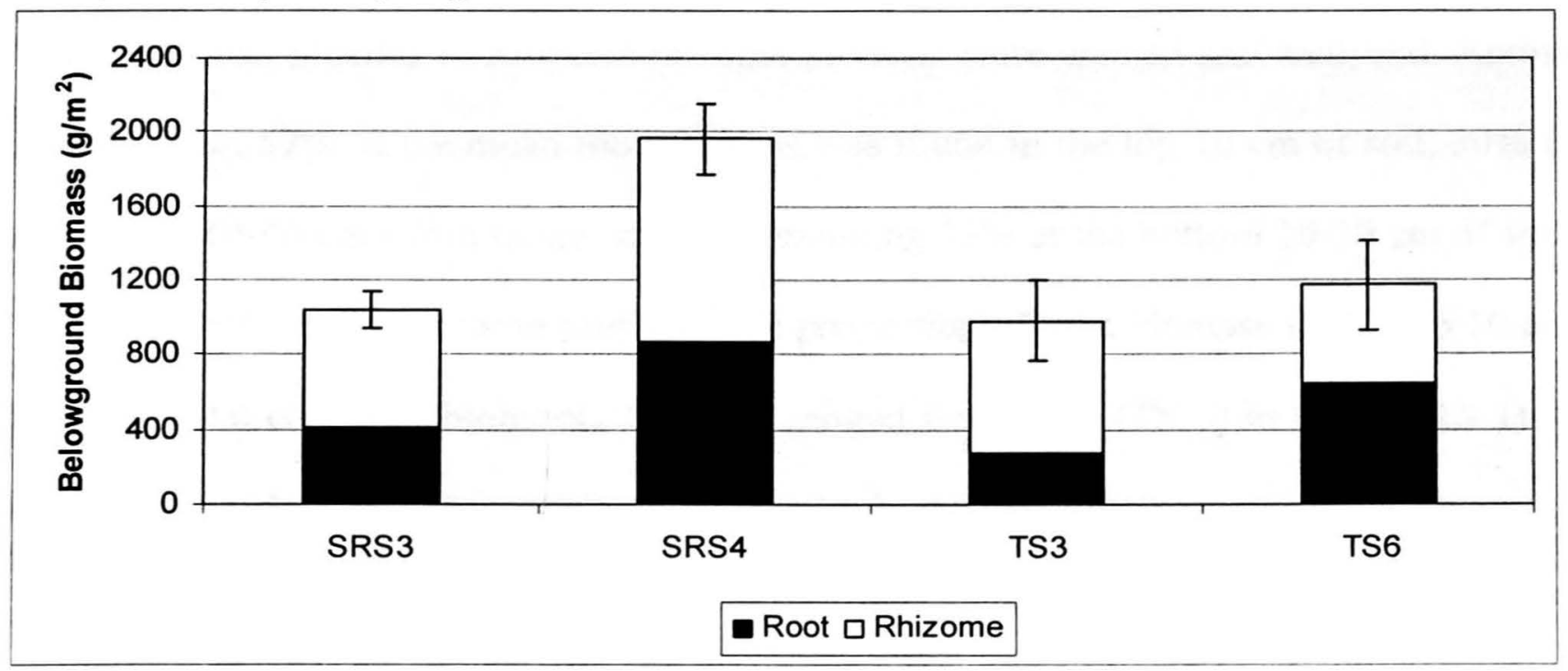

B) July Sampling

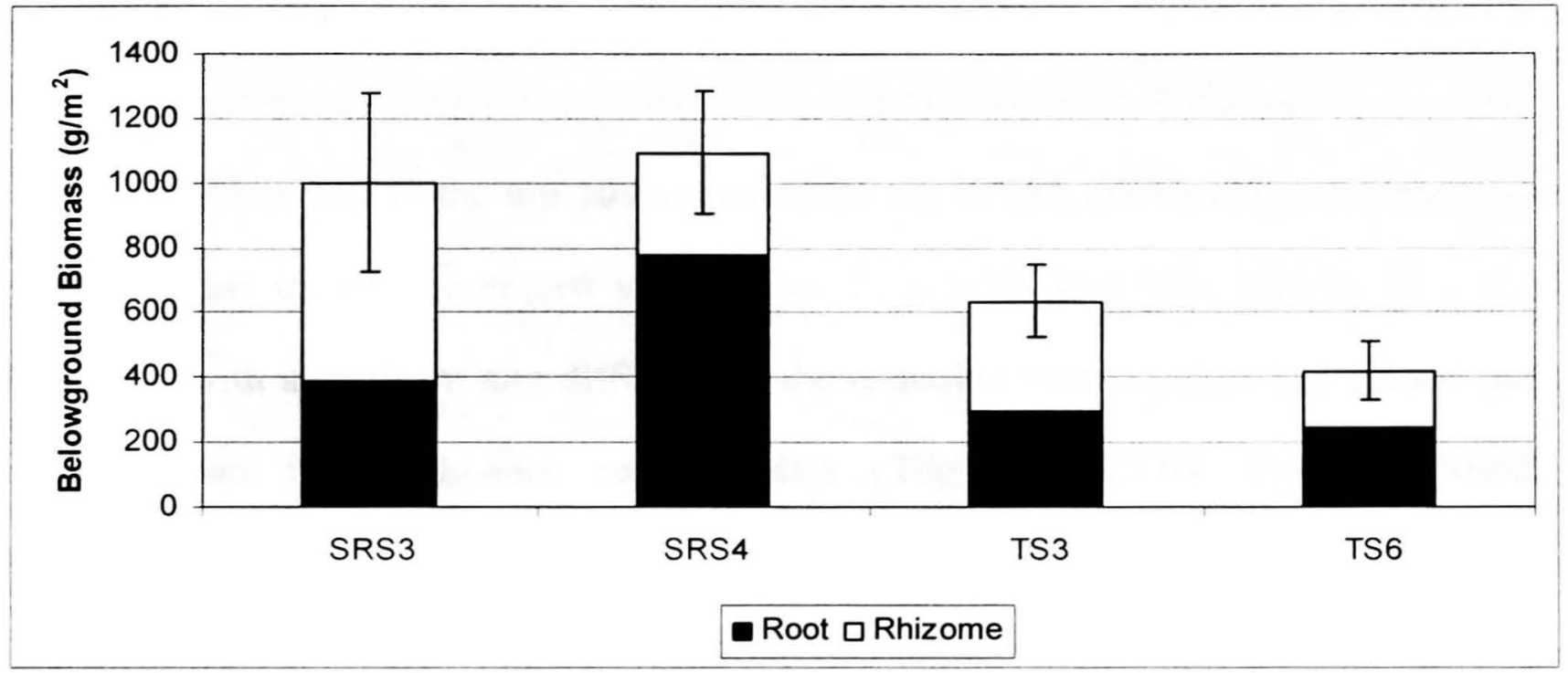

than the freshwater ecotone sites. However, no difference in root biomass between the January and July samplings was found. As with root biomass, rhizome biomass was significantly higher in $\operatorname{SRS}\left(\mathrm{F}_{1,33}=4.12, \mathrm{P}=0.058\right)$. Rhizome biomass varied between 
sampling events as well, with significantly less biomass in July $(\mathrm{F}=11.76, \mathrm{P}=0.003)$. No significant differences were present in thizome biomass between the freshwater and estuarine ecotone sites.

Vertical profiles of root and rhizome biomass were created and analyzed. Across the four sites, $57 \%$ of the mean root biomass was found in the top $10 \mathrm{~cm}$ of soil, $30 \%$ in the middle $10-20 \mathrm{~cm}$ depth range, and the remaining $13 \%$ at the bottom $20-30 \mathrm{~cm}$ of soil. Individual sites varied in these profiles. The proportion of root biomass in the top $10 \mathrm{~cm}$ of soil to total core root biomass $(0-30 \mathrm{~cm})$ ranged from $34 \%$ (TS-3) to $65 \%$ (SRS-3) in January and $40 \%$ (SRS-4) to $84 \%$ (TS-6) in July. In the middle $10 \mathrm{~cm}$, mean root biomass ratios had similar ranges between sampling events, $18 \%$ (SRS-3) to $45 \%$ (TS-3) of the total root biomass in January and $13 \%$ (TS-6) to $45 \%$ (SRS-4) in July. Average root biomass proportions of the bottom $10 \mathrm{~cm}$ of soil ranged from $9 \%$ (SRS-4) to $21 \%$ (TS-3) in January and from $3 \%$ (TS-6) to $16 \%$ (TS-3) in July (Figure 5a \& 5b).

Root biomass in the top $10 \mathrm{~cm}$ and $10-20 \mathrm{~cm}$ of soil showed significantly higher mean biomass in SRS compared to TS (Top: $F_{1.33}=9.19, P=0.008$; Middle: $F_{1,33}=7.94$, $\mathrm{P}=0.012$ ), with significant site differences: the estuarine ecotone sites had greater mean biomass than the freshwater ecotone sites (Top: $F_{1,33}=11.03, P=0.004$; Middle: $\left.F_{1,33}=19.56, P=0.001\right)$. At $20-30 \mathrm{~cm}$ of soil, $S R S$ had significantly higher average biomass than $\mathrm{TS}\left(\mathrm{F}_{1.33}=4.29, \mathrm{P}=0.054\right)$. There were no differences between sampling events in any of the soil layers but a sampling date-site interaction effect was found in the top $10 \mathrm{~cm}$ section $\left(\mathrm{F}_{1,33}=5.28, \mathrm{P}=0.035\right)$. Mean root biomass at $0-10 \mathrm{~cm}$ depth in January at SRS-4 \& TS-6 was significantly higher than in July. In contrast, root biomass in the freshwater sites at the same depth range was greater in July. 
Rhizome biomass profiles were quite different from the root profiles. On average, $78 \%$ of all rhizome biomass was found in the top $10 \mathrm{~cm}$ of soil at all sites, with $16 \%$ in the $10-20 \mathrm{~cm}$ depths, and the remaining $6 \%$ from $20-30 \mathrm{~cm}$ (Figure $5 \mathrm{c} \& 5 \mathrm{~d}$ ). In six of the eight biomass samplings, at least $80 \%$ of the total mean rhizome biomass was found in the top $10 \mathrm{~cm}$ of soil. The only exceptions to this were at SRS-3 in July and at TS-3 in January, where $54 \%$ and $34 \%$ of total mean rhizome biomass was found in the top $10 \mathrm{~cm}$, respectively. The proportion of total mean rhizome biomass found at $10-20 \mathrm{~cm}$ ranged from $3 \%$ (SRS-4) to $53 \%$ (TS-3) in January and from $0 \%$ (TS-6) to $20 \%$ (SRS-3) in July. This range was much smaller at $20-30 \mathrm{~cm}$ depth, with proportions of total mean rhizome biomass from $0 \%$ (TS-6) to $12 \%$ (TS-3) in January and $0 \%$ (TS-6) to $25 \%$ (SRS-3) in July. Half of the $20-30 \mathrm{~cm}$ deep samples lacked rhizome biomass altogether. Because such a large proportion of rhizome biomass occurred in the top $10 \mathrm{~cm}$ of soil, statistics were not run on the separate soil depths.

For whole-core root biomass, $\mathrm{P}$ content showed significant differences between sampling events, transects, and sites (Table 3 ). Root $\mathrm{P}$ concentrations were considerably higher in January $\left(\mathrm{F}_{1,17}=52.44, \mathrm{P}<0.001\right)$, in SRS compared with TS $\left(\mathrm{F}_{1,17}=250.46\right.$, $\mathbf{P}<0.001$ ), and at the estuarine ecotone sites compared with the freshwater sites $\left(\mathrm{F}_{1.17}=11.85, \mathrm{P}=0.003\right)$. A sampling event-transect interaction effect was also evident $\left(\mathrm{F}_{1,17}=8.95, \mathrm{P}=0.008\right)$. Paralleling the standing stock root $\mathrm{P}$ data, rhizome $\mathrm{P}$ content was significantly higher in January $\left(\mathrm{F}_{1,17}=8.55, \mathrm{P}=0.010\right)$ and in $\mathrm{SRS}\left(\mathrm{F}_{1,17}=141.61, \mathrm{P}<0.001\right)$. No significant site difference in $\mathrm{P}$ concentrations was evident, however there was a strong transect-site interaction effect $\left(\mathrm{F}_{1,17}=46.67, \mathrm{P}<0.001\right)$. Because a majority of the rhizome 
Figure 5: Graphs showing the proportion of total mean $C$. jamaicense root and rhizome biomass in each $10 \mathrm{~cm}$ section of the soil cores. The summation of the three sections yields total mean root or rhizome biomass for each site and sampling event. A) Root biomass profile from the January sampling; B) Root biomass profile (July); C) Rhizome biomass profile (January); and D) Rhizome biomass profile (July).
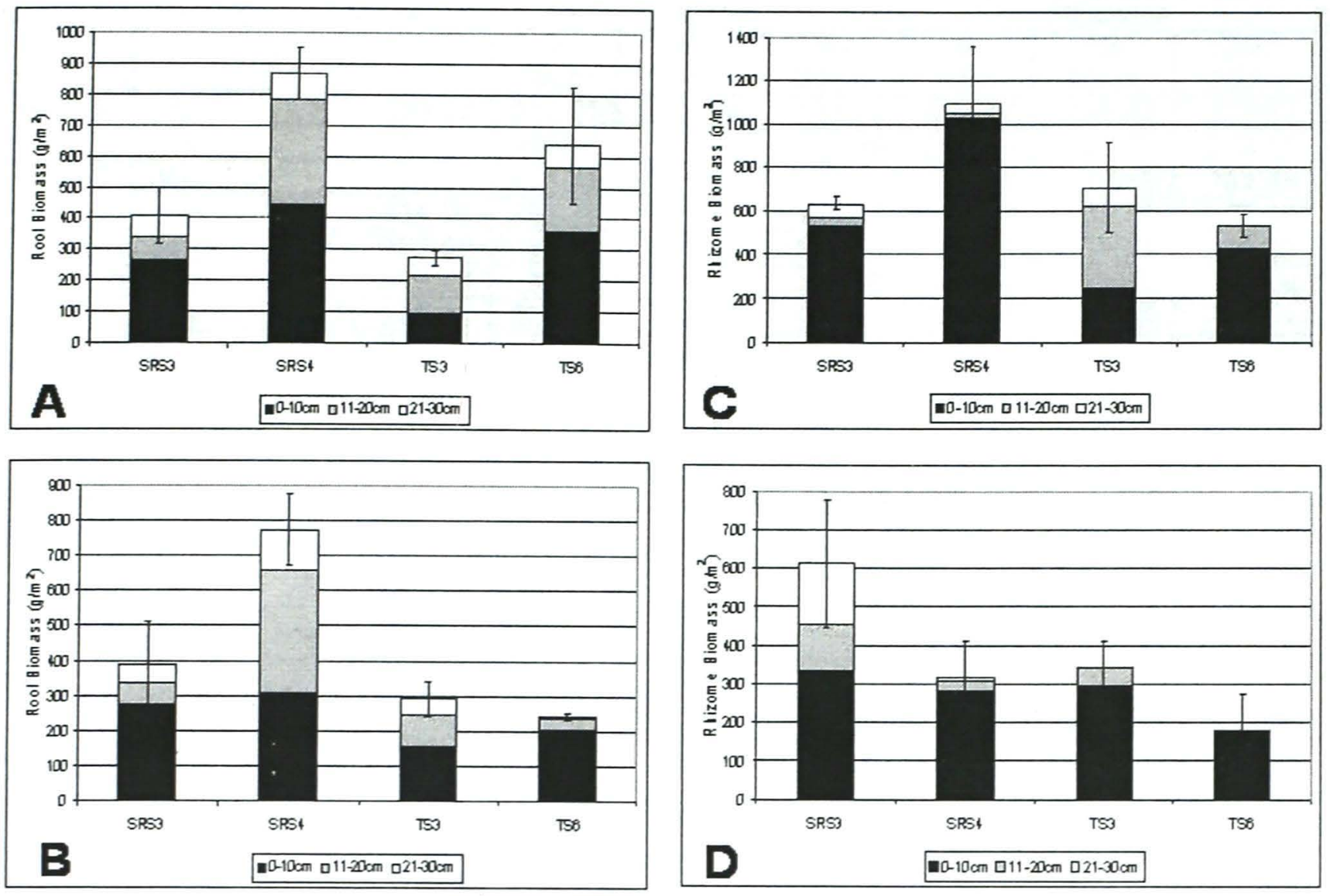

biomass was in the top $10 \mathrm{~cm}$ of soil, statistical comparisons were only examined for this portion of the soil profile.

A stepwise regression was run using four environmental variables (hydroperiod, salinity, water column $\mathrm{P}, \&$ water column $\mathrm{N}$ ) to determine if any one or combination of these could accurately predict the variability in the belowground biomass data. Although hydroperiod explained the variation in belowground biomass better than any other variable, it was only marginally significant $(\mathrm{P}=0.068)$. Aboveground biomass was then 
Table 3: Average P concentrations ( $\mu \mathrm{g} \mathrm{P} / \mathrm{gdw}$ ) of shoot, root, and rhizome standing stock biomass sampled in January and July 2004. " $x$ " denotes either an absence of biomass material in a soil core section or an insufficient amount of dry biomass needed to obtain a tissue $\mathrm{P}$ content.

\begin{tabular}{|l|l|r|r|r|r|r|r|r|}
\hline & & Aboveground & \multicolumn{6}{|c|}{ Belowground } \\
\hline & Sample & Shoot & \multicolumn{1}{c|}{ Root } & \multicolumn{3}{c|}{ Rhizome } \\
\hline & & & $\begin{array}{c}0- \\
10 \mathrm{~cm}\end{array}$ & $\begin{array}{c}10- \\
20 \mathrm{~cm}\end{array}$ & $\begin{array}{c}20- \\
30 \mathrm{~cm}\end{array}$ & $\begin{array}{c}0- \\
10 \mathrm{~cm}\end{array}$ & $\begin{array}{c}10- \\
20 \mathrm{~cm}\end{array}$ & $\begin{array}{c}20- \\
30 \mathrm{~cm}\end{array}$ \\
\hline \multirow{2}{*}{ SRS-3 } & Jan. & 284.02 & 243.07 & 320.46 & 308.70 & 279.14 & 203.42 & 200.33 \\
\cline { 2 - 9 } & July & 381.52 & 208.51 & 199.53 & 216.88 & 210.60 & 181.77 & 208.10 \\
\hline \multirow{2}{*}{ SRS-4 } & Jan. & 326.68 & 464.42 & 270.21 & 227.55 & 178.45 & 148.16 & 198.46 \\
\cline { 2 - 9 } & July & 314.97 & 293.75 & 177.43 & 166.07 & 156.85 & 109.75 & 76.15 \\
\hline \multirow{2}{*}{ TS-3 } & Jan. & 292.68 & 60.14 & 119.82 & 131.50 & 53.65 & 31.91 & 30.53 \\
\cline { 2 - 9 } & July & 219.22 & 31.42 & 106.77 & 72.35 & 42.71 & 83.45 & $\mathrm{x}$ \\
\hline \multirow{2}{*}{ TS-6 } & Jan. & 260.06 & 220.26 & 129.96 & 120.51 & 125.31 & 27.52 & $\mathrm{x}$ \\
\cline { 2 - 9 } & July & 240.23 & 115.40 & 113.35 & 82.03 & 103.55 & $\mathrm{x}$ & $\mathrm{x}$ \\
\hline
\end{tabular}

Figure 6: Graph showing mean $C$. jamaicense aboveground biomass at each sampling site in January and July samplings (2004).

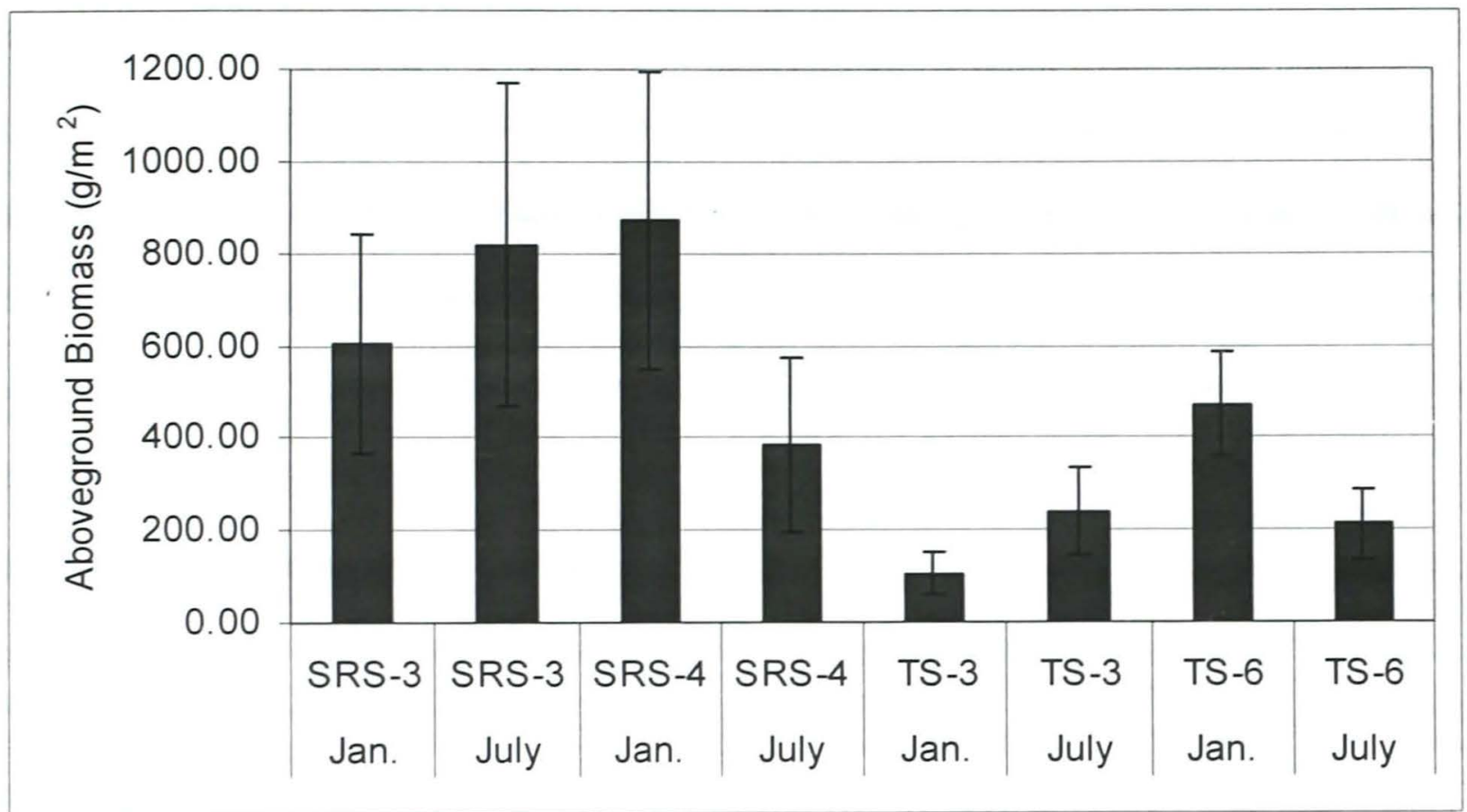

incorporated as a factor into the regression, but this again resulted in no significant outcome. 


\section{Aboveground Standing Stock Biomass}

Aboveground biomass of $C$. jamaicense marshes in the oligohaline ecotone showed considerable variation (Figure 6). Mean aboveground biomass estimates ranged from 106 (TS-3) to $870 \mathrm{gdw} / \mathrm{m}^{2}$ (SRS-4). Across all four sites, the average aboveground biomass was $463 \mathrm{gdw} / \mathrm{m}^{2}$. SRS had significantly larger aboveground biomass than TS $\left(\mathrm{F}_{1,32}=7.74, \mathrm{P}=0.009\right)$. No site differences or differences between January and July samplings were present. Shoot tissue $\mathrm{P}$ content was similar among all sites.

\section{Aboveground:Belowground Biomass Ratio}

As with aboveground biomass, there was a great deal of variability in the aboveground:belowground biomass ratios (Figure 7). Mean A:B ratios ranged from 0.11 at TS-3 in January to 0.82 at SRS-3 in July, with the average A:B ratio across all four sites of 0.45 . Again, the mean A:B ratio in SRS was significantly greater than that of TS $\left(\mathrm{F}_{1,32}=8.80, \mathrm{P}=.009\right)$. A transect-site interaction effect indicated that the patterns between sites within a slough were different between the sloughs $\left(\mathrm{F}_{1,32}=9.75, \mathrm{P}=0.007\right)$. In SRS, the mean $\mathrm{A}: \mathrm{B}$ ratio was significantly higher at the freshwater site, while the biomass ratio was significantly higher at the southern site in TS. Mean A:B ratios were similar between January and July samplings.

\section{Belowground Primary Productivity}

\section{Belowground Primary Productivity from 12-month Ingrowth Cores}

In the oligohaline ecotone of the Everglades, the annual BPP in C. jamaicense marshes ranged from 229 (SRS-4) to $549 \mathrm{gdw} / \mathrm{m}^{2} / \mathrm{yr}$ (TS-6) (Figure 8) with an average of $448 \mathrm{gdw} / \mathrm{m}^{2} / \mathrm{yr}$ across all sites. BPP had no significant differences between transect or site. Partitioning these data into root productivity and rhizome productivity, however, 
Figure 7: Graph of mean C. jamaicense aboveground:belowground biomass ratios at each sampling site in the January and July sampling events of 2004.

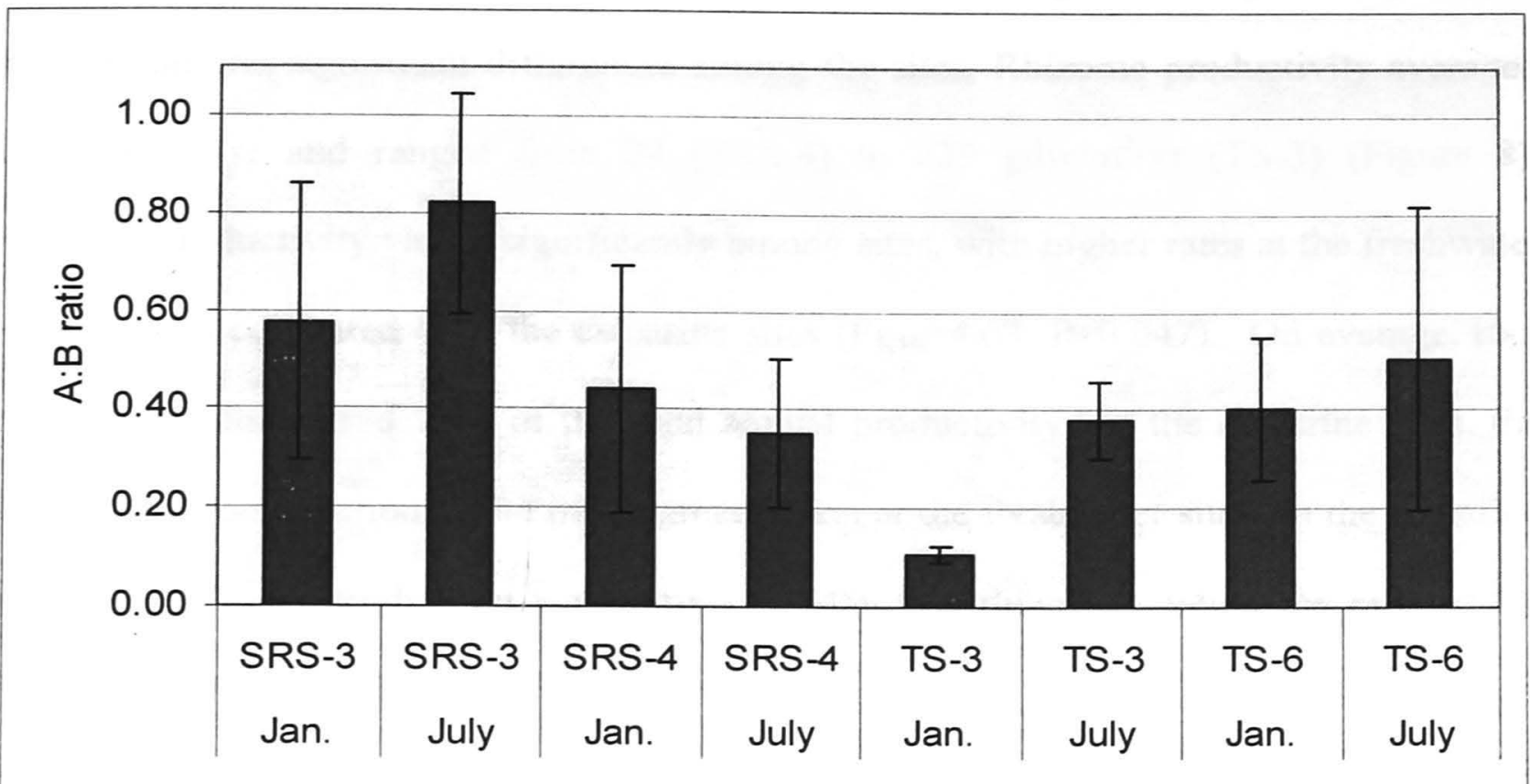

Figure 8: Mean annual BPP for C. jamaicense at the four sampling sites within the oligohaline ecotone. In general, annual root production greatly exceeds annual rhizome production.

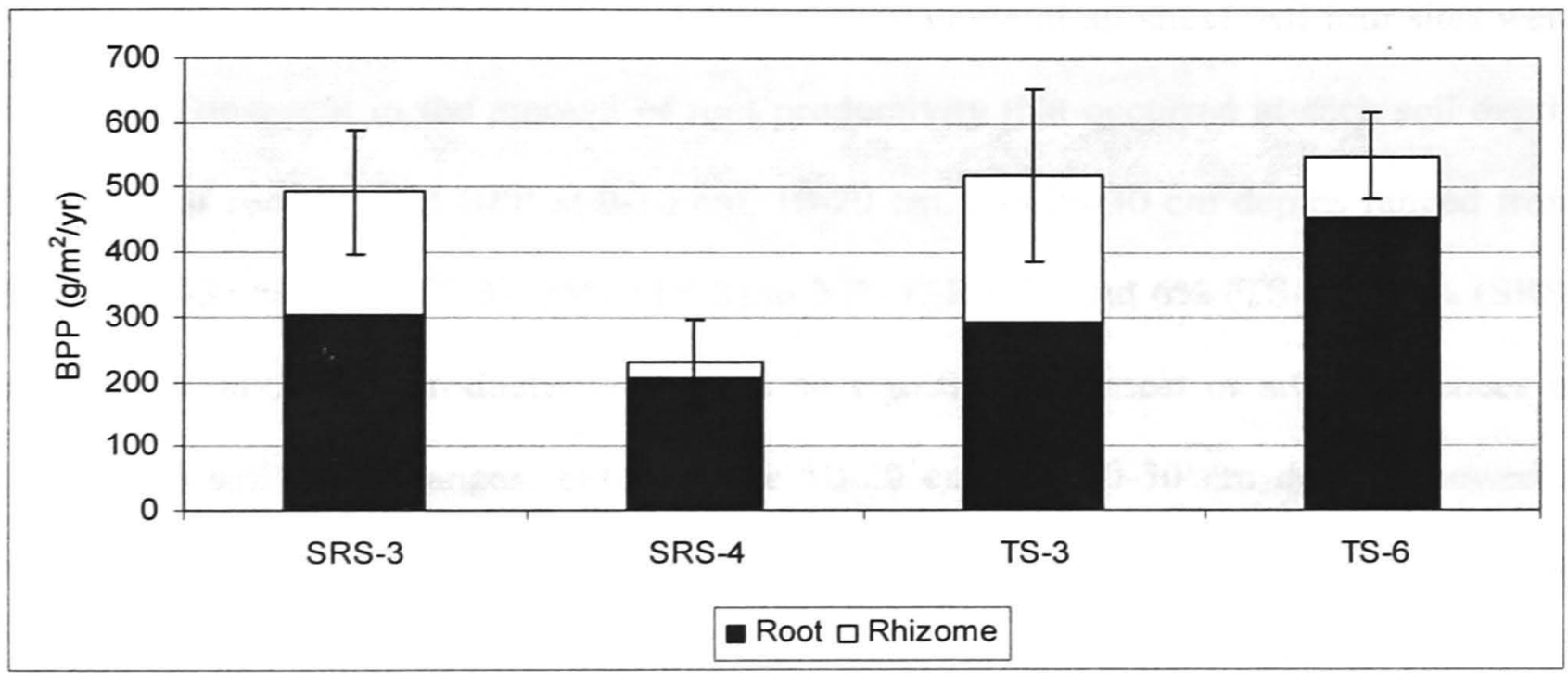


produced different patterns of variability. Annual root productivity ranged from 206 (SRS-4) to $453 \mathrm{gdw} / \mathrm{m}^{2} / \mathrm{yr}$ (TS-6) (Figure 8), with an average of $314 \mathrm{gdw} / \mathrm{m}^{2} / \mathrm{yr}$ across the sites and no significant differences among the sites. Rhizome productivity averaged $134 \mathrm{gdw} / \mathrm{m}^{2} / \mathrm{yr}$ and ranged from 24 (SRS-4) to $229 \mathrm{gdw} / \mathrm{m}^{2} / \mathrm{yr}$ (TS-3) (Figure 8). Rhizome productivity varied significantly among sites, with higher rates at the freshwater ecotone sites compared with the estuarine sites $\left(\mathrm{F}_{1,16}=4.63, \mathrm{P}=0.047\right)$. On average, root productivity comprised $72 \%$ of the total annual productivity. At the estuarine sites, the annual BPP root fractions were much greater than at the freshwater sites. In the estuarine sites $86 \%$ of total production was roots and $14 \%$ was rhizomes, while the ratio at the freshwater sites was $59 \%$ to $41 \%$.

The annual root productivity profile differed from the annual rhizome productivity profile. Only one ingrowth bag produced rhizomes below $10 \mathrm{~cm}$. This bag was incubated at TS-3 and the rhizomes grew into the $10-20 \mathrm{~cm}$ layer. On average, $65 \%$ of roots were produced above $10 \mathrm{~cm}$ deep, $27 \%$ grew at $10-20 \mathrm{~cm}$, and the remaining $8 \%$ were found in the $20-30 \mathrm{~cm}$ soil depth range (average of all sites). All four sites were relatively consistent in the amount of root productivity that occurred at each soil depth. The ratio of root to total BPP at $0-10 \mathrm{~cm}, 10-20 \mathrm{~cm}$, and $20-30 \mathrm{~cm}$ depths ranged from $61 \%$ (SRS-3) to $69 \%$ (TS-3), $25 \%$ (TS-3) to $30 \%$ (SRS-3), and $6 \%$ (TS-3) to $9 \%$ (SRS3), respectively. Root productivity showed no significant transect or site differences in any of the soil depth ranges, but both the $10-20 \mathrm{~cm}$ and $20-30 \mathrm{~cm}$ depths showed a transect-site interaction $\left(\mathrm{F}_{1,16}=4.42, \mathrm{P}=0.052 ; \mathrm{F}_{1,16}=4.41, \mathrm{P}=0.052\right.$ relatively $)$. At these soil depths, root productivity in SRS was significantly greater at the freshwater site (SRS- 
Table 4: Average $\mathrm{P}$ concentrations ( $\mu \mathrm{g} \mathrm{P} / \mathrm{gdw}$ ) of $C$. jamaicense roots and rhizomes that were produced over the 3,6 , or 12 -month productivity intervals. No rhizomes were found below $20 \mathrm{~cm}$ deep. The Shoot column corresponds to $C$. jamaicense shoots that originated from within the ingrowth cores. " $x$ " denotes either a complete absence of roots/rhizomes/shoots in a sample or an insufficient amount of dry plant material needed to obtain tissue $\mathrm{P}$ content.

\begin{tabular}{|c|c|c|c|c|c|c|c|}
\hline & \multirow[b]{2}{*}{ Interval } & \multirow{2}{*}{$\frac{\text { Aboveground }}{\text { Shoot }}$} & \multicolumn{5}{|c|}{ Belowground } \\
\hline & & & \multicolumn{3}{|c|}{ Root } & \multicolumn{2}{|c|}{ Rhizome } \\
\hline \multicolumn{2}{|c|}{$\begin{array}{l}\text { 12-month Ingrowth } \\
\text { Cores }\end{array}$} & & $0-10 \mathrm{~cm}$ & $\begin{array}{c}10- \\
20 \mathrm{~cm}\end{array}$ & $\begin{array}{c}20- \\
30 \mathrm{~cm}\end{array}$ & $0-10 \mathrm{~cm}$ & $10-20 \mathrm{~cm}$ \\
\hline SRS-3 & Annual & 783.11 & 439.04 & 1218.06 & 892.21 & 1027.29 & $x$ \\
\hline SRS-4 & Annual & 1203.65 & 424.67 & 452.40 & 696.33 & 1324.57 & $x$ \\
\hline TS-3 & Annual & 508.34 & 379.14 & 801.18 & 1292.35 & 1383.89 & 579.31 \\
\hline TS-6 & Annual & 831.28 & 540.27 & 1447.08 & 1147.62 & 1127.55 & $x$ \\
\hline \multicolumn{8}{|c|}{ 6-month Ingrowth Cores } \\
\hline \multirow[t]{2}{*}{ SRS-3 } & Dry & 2652.59 & 832.05 & 1029.00 & 416.53 & 1620.80 & 1500.21 \\
\hline & Wet & $x$ & 1462.96 & 1558.09 & 568.53 & $\mathrm{x}$ & $x$ \\
\hline \multirow[t]{2}{*}{ SRS-4 } & Dry . & $x$ & 908.93 & 1250.86 & 2054.03 & 629.42 & $x$ \\
\hline & Wet & $x$ & 1848.55 & 1739.72 & 1379.86 & 1069.21 & $x$ \\
\hline \multirow[t]{2}{*}{ TS-3 } & Dry & 807.79 & 561.17 & 656.64 & 818.01 & 1163.28 & $x$ \\
\hline & Wet & 1070.50 & 1516.64 & 1689.66 & 897.26 & 1802.99 & $x$ \\
\hline \multirow[t]{2}{*}{ TS-6 } & Dry & $x$ & 1753.15 & 1422.13 & 752.05 & 1494.11 & $x$ \\
\hline & Wet & 1040.17 & 759.74 & 749.70 & 633.17 & $x$ & $x$ \\
\hline \multicolumn{8}{|c|}{ 3-month Ingrowth Cores } \\
\hline \multirow[t]{4}{*}{ SRS-3 } & Feb-Apr & $x$ & 743.18 & 1020.02 & 613.71 & 1016.23 & $x$ \\
\hline & May-Jul & $x$ & 1616.08 & 1205.37 & 670.67 & 913.74 & $x$ \\
\hline & Aug-Oct & 542.12 & 2059.96 & $x$ & 1750.27 & $x$ & $x$ \\
\hline & Nov-Jan'05 & $x$ & 1260.63 & $x$ & 605.85 & $\mathrm{x}$ & $x$ \\
\hline \multirow[t]{4}{*}{ SRS-4 } & Feb-Apr & $x$ & 3620.64 & 3222.48 & $x$ & 837.77 & 794.78 \\
\hline & May-Jul & $x$ & 1883.26 & 1752.05 & 636.56 & $x$ & $x$ \\
\hline & Aug-Oct & $x$ & 876.95 & $x$ & $x$ & $\mathrm{X}$ & $x$ \\
\hline & Nov-Jan'05 & $x$ & 1138.88 & 947.94 & 1127.27 & 657.69 & $x$ \\
\hline \multirow[t]{4}{*}{ TS-3 } & Feb-Apr & $x$ & 2978.99 & 4236.72 & 1386.81 & $\mathrm{X}$ & $x$ \\
\hline & May-Jul & 1767.35 & 1193.14 & 1027.29 & 1143.49 & 1967.60 & $x$ \\
\hline & Aug-Oct & $x$ & $x$ & $x$ & $x$ & $\mathrm{x}$ & $x$ \\
\hline & Nov-Jan'05 & $x$ & $x$ & $x$ & $x$ & $\mathrm{X}$ & $x$ \\
\hline \multirow[t]{4}{*}{ TS-6 } & Feb-Apr & $x$ & 2908.00 & 3262.39 & 1340.05 & $\mathrm{X}$ & $x$ \\
\hline & May-Jul & 1193.81 & 1204.59 & 2215.22 & 708.44 & 424.56 & $x$ \\
\hline & Aug-Oct & $x$ & 1211.99 & $x$ & $x$ & $\mathrm{X}$ & $x$ \\
\hline & Nov-Jan'05 & $x$ & 1931.47 & 1882.91 & $x$ & $\mathrm{X}$ & $x$ \\
\hline
\end{tabular}


3>SRS-4), while the estuarine site in TS had significantly greater root productivity (TS6>TS-3).

The mean root $\mathrm{P}$ content (whole core) showed a significant transect difference $\left(F_{1,8}=13.96, P=0.006\right)$, with TS having a higher root $P$ content than SRS (Table 4). The transect-site interaction was also significant $\left(\mathrm{F}_{1,8}=16.99, \mathrm{P}=0.003\right)$, demonstrating that root $\mathrm{P}$ content in the two sloughs responded differently based on location in the ecotone. In SRS, root $\mathrm{P}$ content was significantly higher at the freshwater site compared with the estuarine site, while the opposite was true in TS. No significant differences in rhizome $\mathrm{P}$ content were seen.

\section{Belowground Primary Productivity from 6-month Ingrowth Cores}

The six-month $C$. jamaicense belowground productivity data provided strong evidence of seasonal variation. Across the four sampling sites, total belowground productivity averaged $56.30 \mathrm{gdw} / \mathrm{m}^{2} / \mathrm{mo}$ in the dry season and $14.76 \mathrm{gdw} / \mathrm{m}^{2} / \mathrm{mo}$ in the wet season. Mean dry season productivity ranged from 42.22 (SRS-4) to 71.51 $\mathrm{gdw} / \mathrm{m}^{2} / \mathrm{mo}$ (TS-6), whereas this range spanned from 8.86 (SRS-4) to $18.69 \mathrm{gdw} / \mathrm{m}^{2} / \mathrm{mo}$ (TS-6) in the wet season (Figure 9). This seasonal difference was significant $\left(\mathrm{F}_{1,33}=31.14\right.$, $\mathrm{P}<0.001$ ) with more productivity occurring in the dry season. No transect or site differences existed.

Root productivity and rhizome productivity showed seasonal trends similar to the total 6-month belowground productivity. Dry season root productivity significantly exceeded that of the wet season $\left(F_{1.33}=30.05, P<0.001\right)$. Average dry season root productivity was $47.32 \mathrm{gdw} / \mathrm{m}^{2} / \mathrm{mo}$ compared to $13.12 \mathrm{gdw} / \mathrm{m}^{2} / \mathrm{mo}$ in the wet season. Dry and wet season production had respective ranges of 35.80 (SRS-3) to $68.15 \mathrm{gdw} / \mathrm{m}^{2} / \mathrm{mo}$ 
(TS-6) and 8.29 (SRS-4) to $18.60 \mathrm{gdw} / \mathrm{m}^{2} / \mathrm{mo}$ (TS-6). Rhizome productivity in the dry season was significantly greater than in the wet season $\left(\mathrm{F}_{1,33}=5.56, \mathrm{P}=0.025\right)$. Mean dry season productivity ranged from 19.59 (SRS-3) to $1.571 \mathrm{gdw} / \mathrm{m}^{2} / \mathrm{mo}$ (SRS-4) with an average of $8.99 \mathrm{gdw} / \mathrm{m}^{2} / \mathrm{mo}$. The corresponding wet season average was 1.64 $\mathrm{gdw} / \mathrm{m}^{2} / \mathrm{mo}$, ranging from 0 (SRS-3) to $5.91 \mathrm{gdw} / \mathrm{m}^{2} / \mathrm{mo}$ (TS-3). The 6-month rhizome productivity data also showed site differences, with significantly more production at the freshwater ecotone sites $\left(\mathrm{F}_{1,33}=6.32, \mathrm{P}=0.017\right)$ (Figure 9). On average, root productivity comprised $84 \%$ of total belowground productivity in the dry season and $82 \%$ in the wet season.

In the dry and wet seasons, $66 \%$ and $64 \%$ of total root productivity occurred in the top $10 \mathrm{~cm}$ of soil, $26 \%$ and $24 \%$ in the $10-20 \mathrm{~cm}$ soil range, and $8 \%$ and $12 \%$ in the $20-30 \mathrm{~cm}$ core section, respectively (Figure 10). The most variation in root productivity was in the top $10 \mathrm{~cm}$. Root productivity in the top $10 \mathrm{~cm}$ of soil was significantly greater in the dry season $\left(\mathrm{F}_{1,33}=46.46, \mathrm{P}<0.001\right)$. No significant transect or site differences existed, but all interaction effects at the $0-10 \mathrm{~cm}$ soil depth were statistically significant. The sites responded differently between the sloughs $\left(\mathrm{F}_{1.33}=6.69, \mathrm{P}=0.014\right)$. In TS, root productivity was significantly higher at the estuarine ecotone site (TS-6>TS-3), whereas in SRS, the freshwater site had higher root productivity (SRS-3>SRS-4). In the transectseason interaction, the root productivity in the sloughs responded differently to season $\left(\mathrm{F}_{1.33}=5.42, \mathrm{P}=0.026\right)$. In the top $10 \mathrm{~cm}$ of soil, the difference in root productivity between seasons in TS was more drastic than in SRS. Root productivity in the estuarine sites was significantly greater than the freshwater sites in the dry season $(S>N)$, where the opposite occurred in the wet season $(\mathrm{S}<\mathrm{N})\left(\mathrm{F}_{1.33}=3.86, \mathrm{P}=0.058\right)$. Root productivity in the 
Figure 9: Mean seasonal BPP for C. jamaicense at the four sampling sites within the oligohaline ecotone. These data are based on the 6-month ingrowth cores and distinctly show seasonal variation in BPP among roots and rhizomes at all sites.

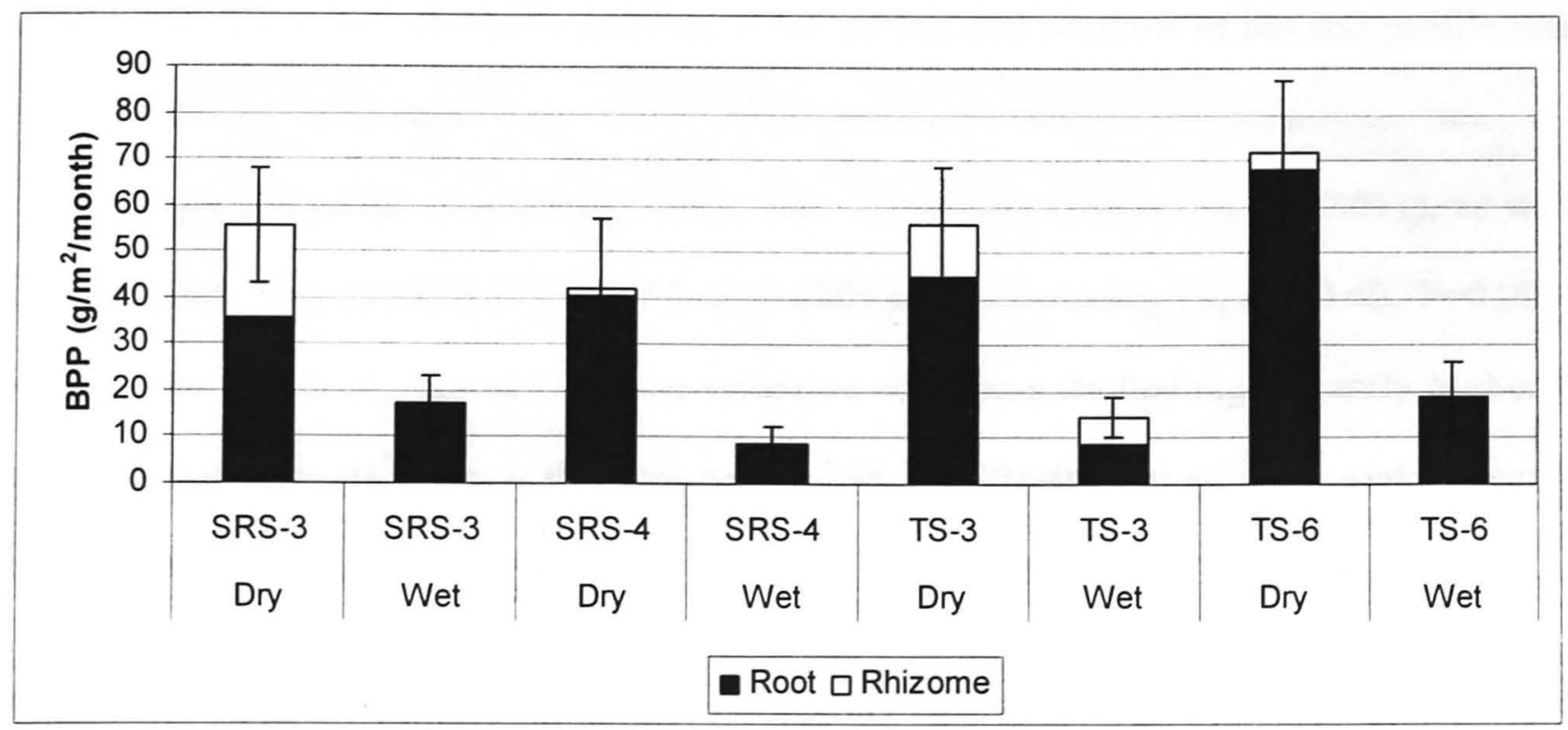

Figure 10: Breakdown of how much root productivity in each $10 \mathrm{~cm}$ section of ingrowth core contributes to total root productivity for $C$. jamaicense of the oligohaline ecotone. The graph displays mean monthly BPP derived from the 6-month ingrowth cores.

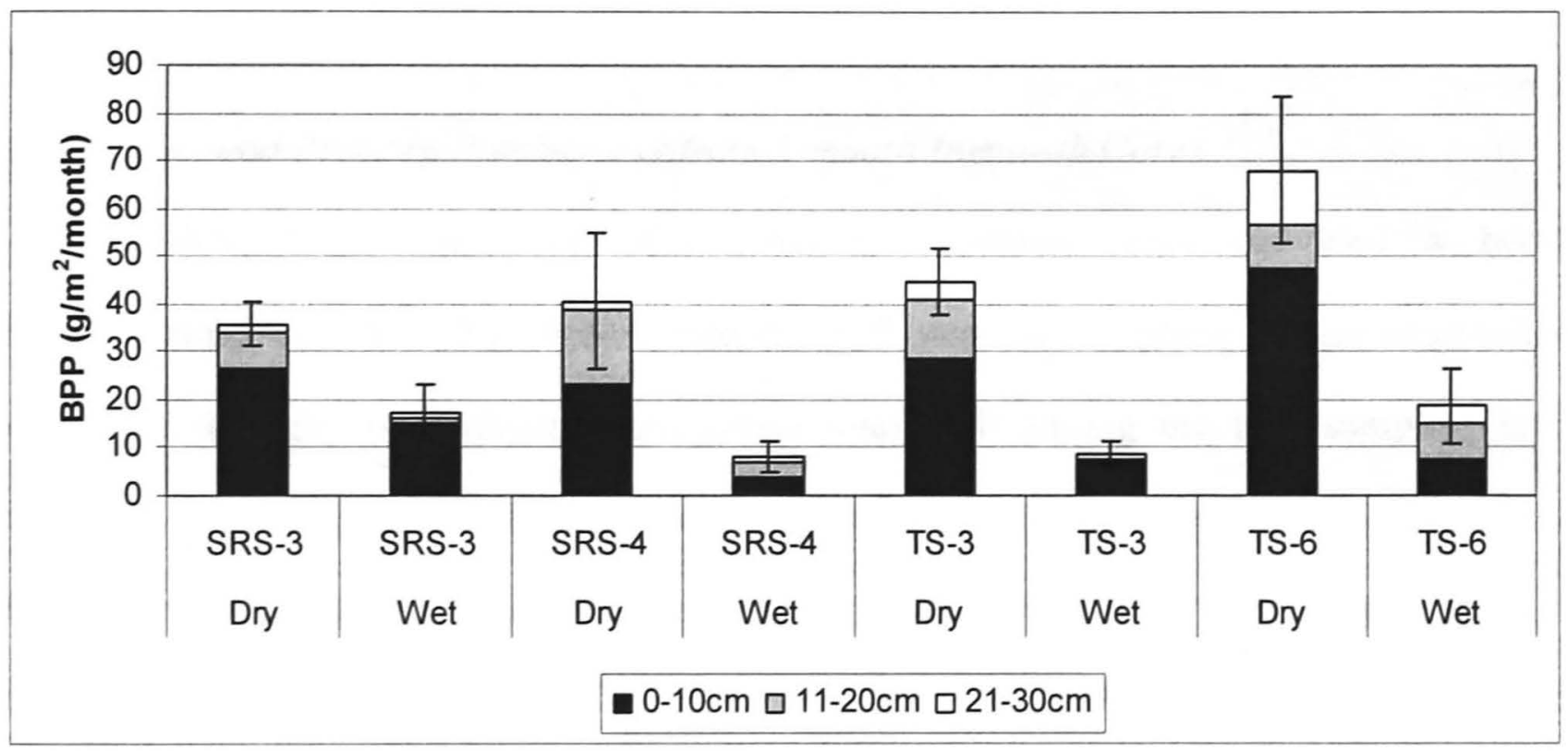


$10-20 \mathrm{~cm}$ section was significantly higher in the dry season $\left(F_{1,33}=11.22, P=0.002\right)$. As with the annual productivity data, $95 \%$ of rhizome production occurred in the top $10 \mathrm{~cm}$ of soil. Therefore, no statistical analysis of the partitioned sections of the soil profile was performed.

Root $P$ content showed significant site differences $\left(F_{1,10}=9.57, P=0.011\right)$, as well as significant transect-site $\left(\mathrm{F}_{1,10}=7.67, \mathrm{P}=0.020\right)$ and site-season $\left(\mathrm{F}_{1,10}=10.60, \mathrm{P}=0.009\right)$ interactions (Table 4). Roots from the estuarine ecotone sites had significantly higher $\mathbf{P}$ content relative to those from the freshwater sites. The freshwater sites showed greater $\mathbf{P}$ concentrations during the dry season, whereas the seasonal root $\mathbf{P}$ levels were similar at the estuarine ecotone sites. The $\mathrm{P}$ content of the rhizomes varied significantly by season $\left(\mathrm{F}_{1,8}=16.80, \mathrm{P}=0.003\right)$ and site $\left(\mathrm{F}_{1,8}=6.92, \mathrm{P}=0.030\right)$, also showing a transect-site interaction effect $\left(\mathrm{F}_{1,8}=27.73, \mathrm{P}=0.001\right)$. Rhizome $\mathrm{P}$ concentrations were greater in the dry season and at the freshwater ecotone sites. P content of rhizomes from SRS-3 greatly exceeded that of SRS-4, whereas the rhizome P content from the two TS sites were similar.

\section{Belowground Primary Productivity from 3-month Ingrowth Cores}

Belowground data from the 3-month ingrowth cores provided a better understanding of when the highest rate of BPP was taking place in the oligohaline ecotone. From the 3-month ingrowth cores, total BPP among the four sampling sites averaged $27.06 \mathrm{gdw} / \mathrm{m}^{2} / \mathrm{mo}$ from February through April (Dry season), $58.58 \mathrm{gdw} / \mathrm{m}^{2} / \mathrm{mo}$ from May through July (Dry-Wet Transition), $4.70 \mathrm{gdw} / \mathrm{m}^{2} / \mathrm{mo}$ from August through October (Wet season), and $14.23 \mathrm{gdw} / \mathrm{m}^{2} / \mathrm{mo}$ from November through January 2005 (Wet-Dry Transition) (Figure 11a). Roots contributed 91\% (24.58 gdw/m $/ 2 / \mathrm{mo}), 87 \%$ 
(51.45 $\left.\mathrm{gdw} / \mathrm{m}^{2} / \mathrm{mo}\right), 91 \%\left(4.28 \mathrm{gdw} / \mathrm{m}^{2} / \mathrm{mo}\right)$, and $94 \%\left(12.94 \mathrm{gdw} / \mathrm{m}^{2} / \mathrm{mo}\right)$ to total BPP during these intervals, respectively (Figure 11b). Rhizome productivity accounted for the remaining BPP (Figure 11c).

The greatest amount of root and total BPP across all sites occurred in the Dry-Wet Transition period (May-July; Figures $11 \mathrm{a} \&$ b). During this three month time interval, I also found significant differences in root and total production between the two transects $\left(F_{3,64}=12.55, P<0.001\right)$, with TS showing higher BPP than SRS. Seasonal differences in productivity were driven by root growth during this time period.

Significant variations in BPP from the 3-month ingrowth cores are shown in Table 5. In general, the greatest variation in BPP occurred when data from the Dry-Wet Transition period were compared to other 3-month time-steps. Transect effects and a transect-season interaction were also apparent. The Tukey's post hoc comparisons for the transect-season interaction effect illustrate how TS root productivity and total BPP in the Dry-Wet Transition period drastically exceed the BPP from any other 3-month sample in either slough (see Table 5 for comparative post-hoc p-values). Rhizome productivity, which did not demonstrate as much variability as the root productivity data, showed no significant transect, site, or temporal differences in the 3-month ingrowth cores (Table 5). The majority of the root productivity in the 3 -month ingrowth cores was in the top $10 \mathrm{~cm}$ of soil (Figure 12). Across all four sites in the Dry-Wet Transition period, the top $10 \mathrm{~cm}$ of roots contributed to $68 \%$ of total core root productivity and roots grown in the $10-20$ $\mathrm{cm}$ range accounted for $20 \%$. Transect and seasonal differences are apparent, with TS having significantly more root productivity than SRS in the Dry-Wet Transition period. A site difference is also present in roots from the top $10 \mathrm{~cm}$ of soil and in the entire core (0- 
Figure 11: Mean C. jamaicense BPP at the oligohaline ecotone sites over each 3-month interval in 2004. From May-July (Dry-Wet Transition), a peak in productivity occurred in TS that was not evident in SRS. Rhizome productivity, which showed a large peak at TS6 from May-July, did not exhibit significant differences in the 3-month ingrowth cores.

\section{A) Total Belowground Productivity}

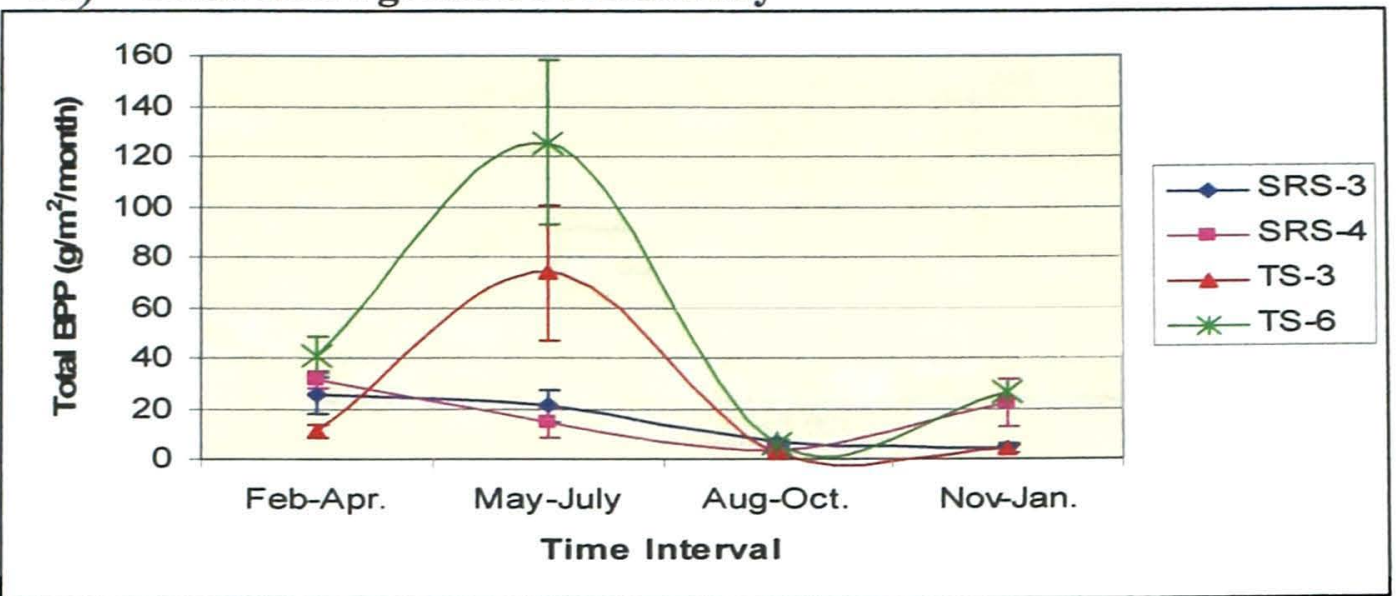

\section{B) Root Productivity}

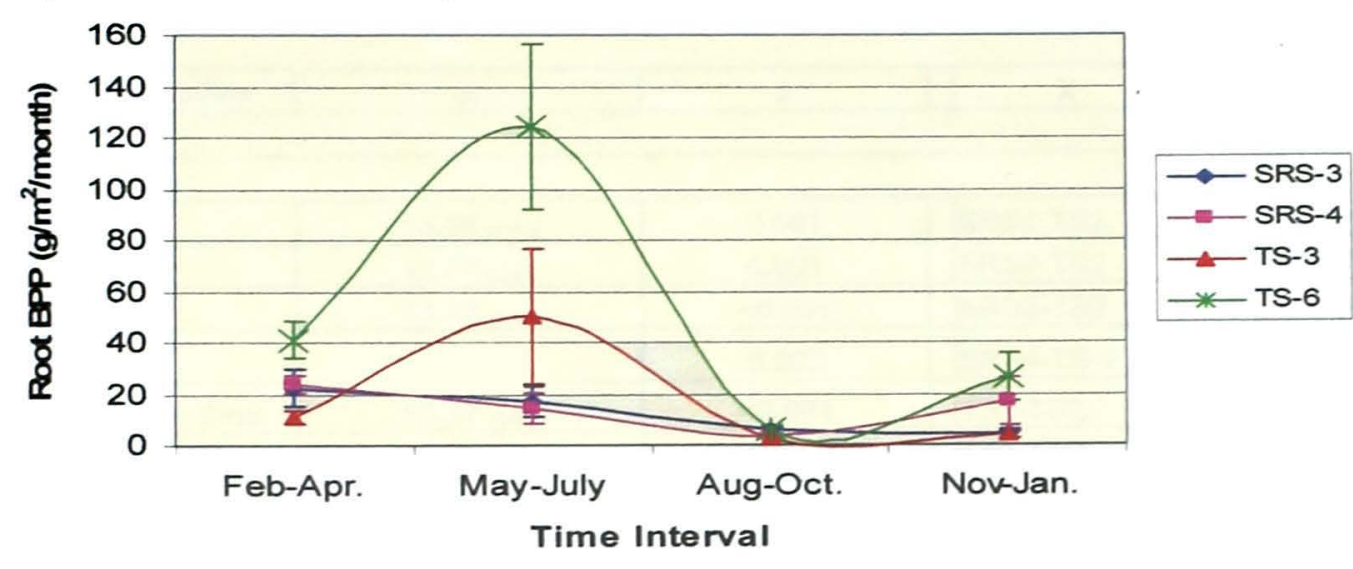

C) Rhizome Productivity

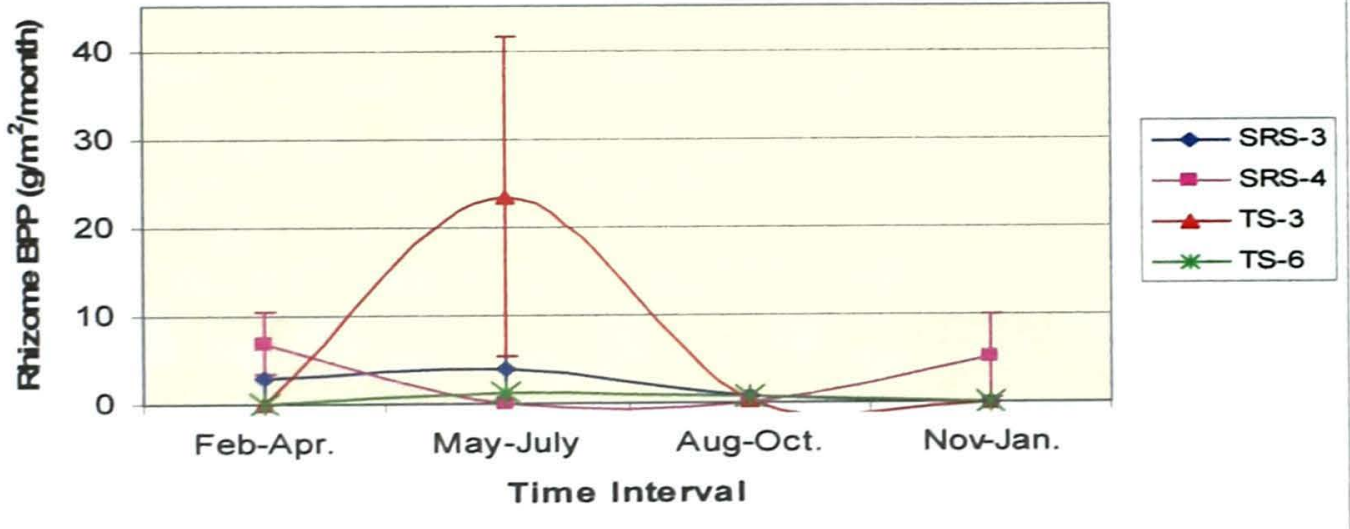


Table 5: Significant variation in BPP from the 3-month ingrowth cores in the oligohaline ecotone. The table lists the F \& p-values for each significant effect. The Tukey's post-hoc comparisons for the transect-season effect are also given. In the "Interaction" column: TS = Taylor Slough, SRS = Shark River Slough, $1=$ Feb-Apr (Dry season), 2 = May-July (Dry-Wet Transition), 3 = Aug-Oct. (Wet season), \& 4 = Nov-Jan '05 (Wet-Dry Transition).

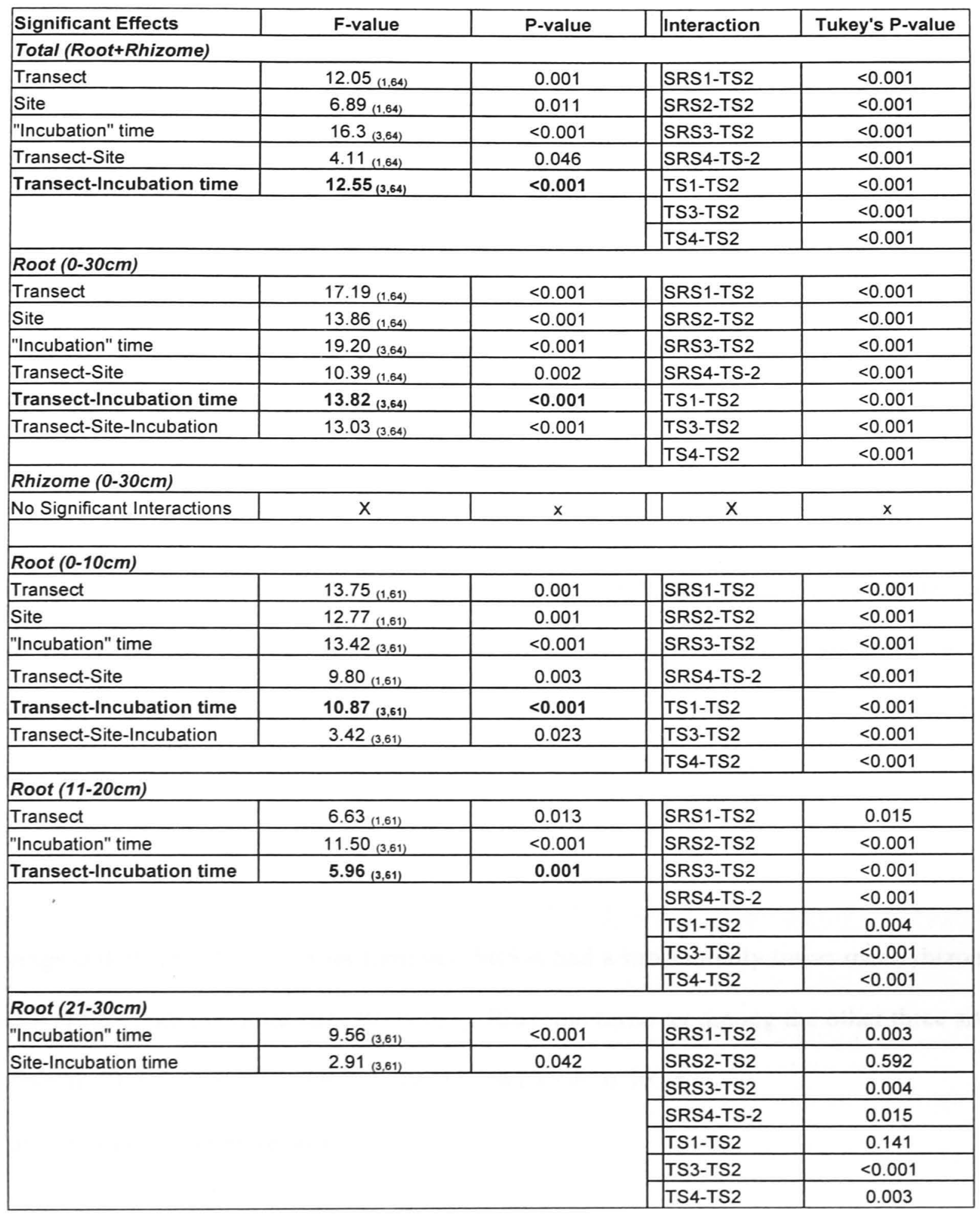


$30 \mathrm{~cm}$ ), with the estuarine ecotone sites showing significantly more productivity than the freshwater sites (see F \& p-values in Table 4).

As with the productivity data, the root $\mathrm{P}$ concentrations from the 3-month ingrowth cores exhibited significant transect variation $\left(F_{1,15}=120.03, P<0.001\right)$, with $T S$ roots having higher $\mathrm{P}$ content than SRS roots (Table 4). Significant seasonal variation in BPP was also evident $\left(F_{3,15}=20.10, P<0.001\right)$. Tukey's post-hoc comparisons showed root P content varied the most between the Dry (Feb-April) and Dry-Wet Transition (MayJuly) samplings. Significant transect and site differences were present, with the rhizomes from TS and the northern sites having higher P content than SRS and the southern sites. No significant seasonal effects were evident.

\section{Turnover}

I calculated turnover rates from the annual productivity values and the root and rhizome biomass estimates. Using the mean belowground biomass data from the January and July sampling events, the average root turnover rate for $C$. jamaicense in the oligohaline ecotone was $0.84 \mathrm{yr}^{-1}$. SRS-4 had a relatively low mean turnover rate compared to the other three sites $\left(0.25 \mathrm{yr}^{-1}\right)$. All other sites showed mean root turnover rates of about one per year (SRS-3: $0.76 \mathrm{yr}^{-1}$; TS-3: $1.03 \mathrm{yr}^{-1}$; and TS-6: $1.29 \mathrm{yr}^{-1}$ ).

Mean rhizome turnover was substantially lower than mean root turnover, averaging $0.30 \mathrm{yr}^{-1}$. As with root turnover, SRS-4 had a substantially lower mean rhizome turnover rate than the other sites $\left(0.05 \mathrm{yr}^{-1}\right)$. Rhizome turnover among the other three sites averaged: SRS-3: $0.30 \mathrm{yr}^{-1}$; TS-3: $0.49 \mathrm{yr}^{-1}$; and TS-6: $0.36 \mathrm{yr}^{-1}$.

\section{Water Level \& Hydroperiod}


Figure 12: Graphs comparing the mean root productivity over 3 -months for each $10 \mathrm{~cm}$ section of ingrowth core. Root productivity in the top $10 \mathrm{~cm}$ of soil greatly exceeded that of the rest of the core and much of the May-July Taylor Slough productivity peak originated from root growth in this upper soil layer.
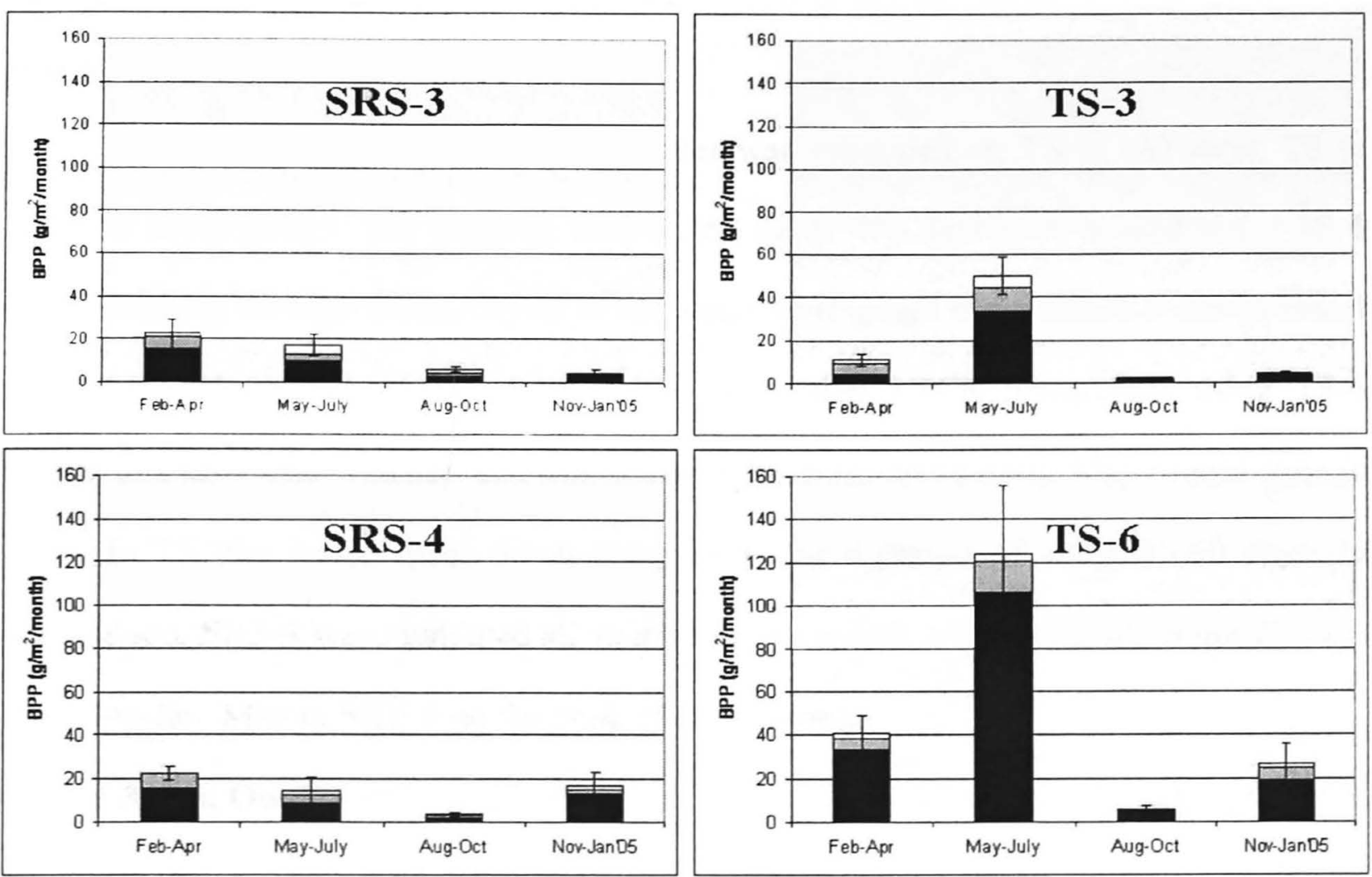

$0-10 \mathrm{~cm} \square 11-20 \mathrm{~cm} \square 21-30 \mathrm{~cm}$

Throughout the year, water level at the TS estuarine ecotone site exceeded that of the freshwater site (Figure 13). In SRS, water levels in the freshwater marsh exceeded those in the estuarine marsh for about 8 months, but were lower during the late dry season and Dry-Wet Transition (April-July). In TS, water levels rose shortly after the onset of the wet season precipitation, in June, and quickly decreased with the approach of the dry season in November. This seasonal pattern was not as clear in SRS. SRS-3 exhibited seasonality in water levels much like those observed in TS; however, at SRS-4 
measured water levels showed both seasonal and tidal influence. Bi-monthly peaks in water level were associated with spring tides. Water depths were greater and hydroperiods were longer in SRS marshes, particularly at SRS-4 where the tidal influence was greatest.

Hydroperiod for the four ecotone sites was estimated at: TS-3: 281 days, TS-6: 300-330 days, SRS-3: 347 days, \& SRS-4 365 days. No data were available for TS-6 from mid-May through early August as the water level gauge experienced some technical difficulties. However, on-site observations from other LTER researchers using TS-6 during this time span verified that this site was dry from about early May to mid June in 2004. In TS, the marsh dried down completely, for a period of about 30-90 days. In comparison, SRS-4 was inundated all year while the marsh dried-down for about 20 days in mid-to-late May at SRS-3 (at the peak of dry season).

\section{Water \& Soil Quality}

Water column $P$ in SRS was relatively higher than in TS (Figure 14). Water column $\mathrm{P}$ was also relatively higher at the estuarine ecotone sites. There was also a trend showing relatively higher $\mathrm{P}$ levels, specifically at the estuarine ecotone sites, in the late dry season (late Mar to mid June). Similarly, soil P content in SRS soils was considerably higher than in TS soils (Figure 15). In both sloughs, mean annual soil $\mathrm{P}$ was also relatively higher at the estuarine ecotone sites.

The freshwater sites exhibited negligible surface water salinity, with no salinity recorded in any point during the experiment at TS-3 and mean salinity readings of $2.8 \mathrm{ppt}$ over 15 days in June at SRS-3 (Figure 16). Salinity at the estuarine ecotone sites was higher than at the freshwater sites, and reached a maximum in SRS much earlier in the 
Figure 13: Average daily water levels measured at the four sites across the oligohaline ecotone. At all sites, the highest recorded water levels occurred in the middle of the wet season (Sept-Oct), with the lowest levels occurring at the end of the dry season (AprJuly). Values below $0 \mathrm{~cm}$ represent a dry-down in the marsh soils.

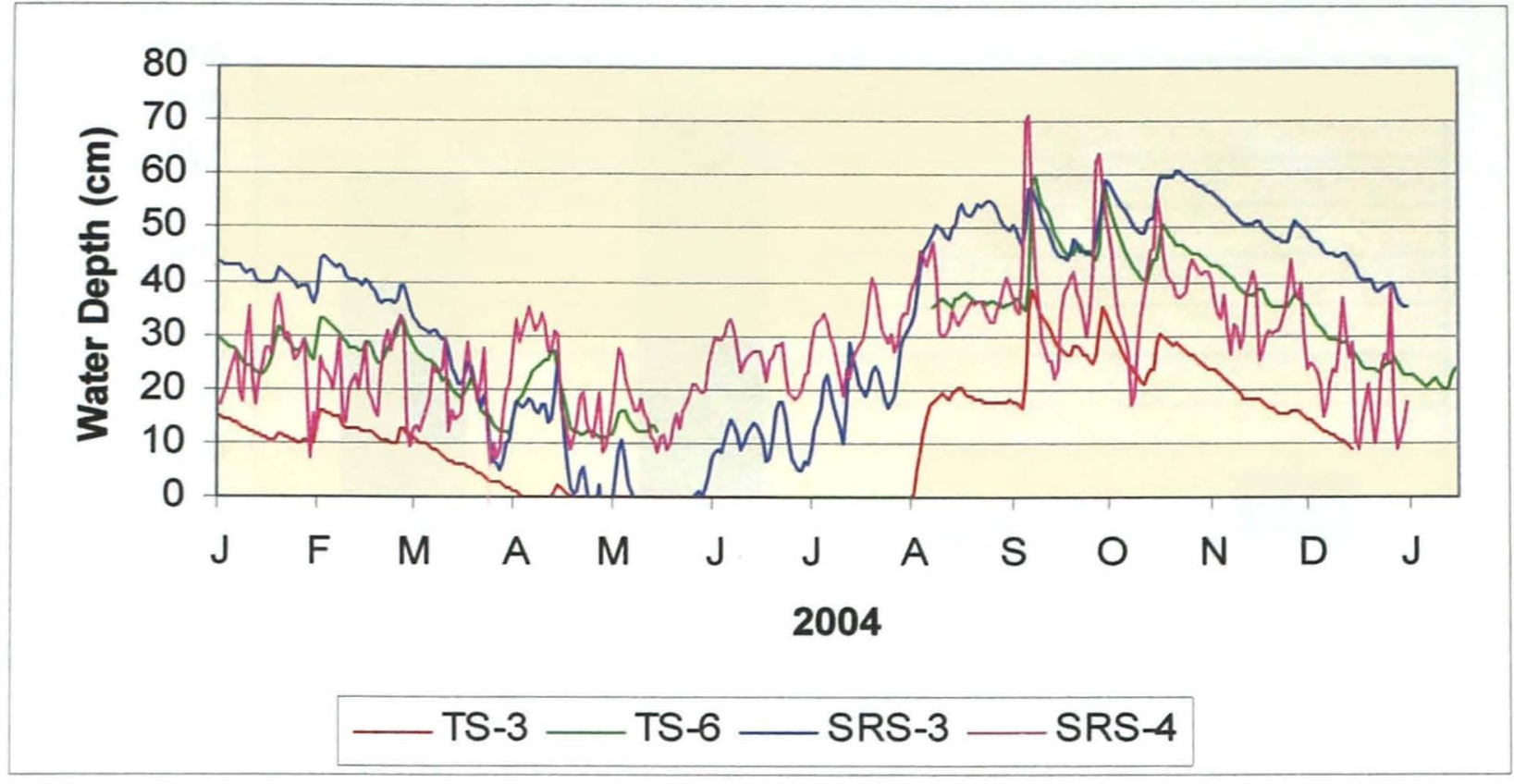

Figure 14: $P$ content of oligohaline ecotone waters at each of the four sampling sites. Breaks in the trend lines indicate missing samples caused by either a lack of water (marsh dry-downs) or technicalities with the automatic water sampler. Each point is the mean of a three-day composite sample.

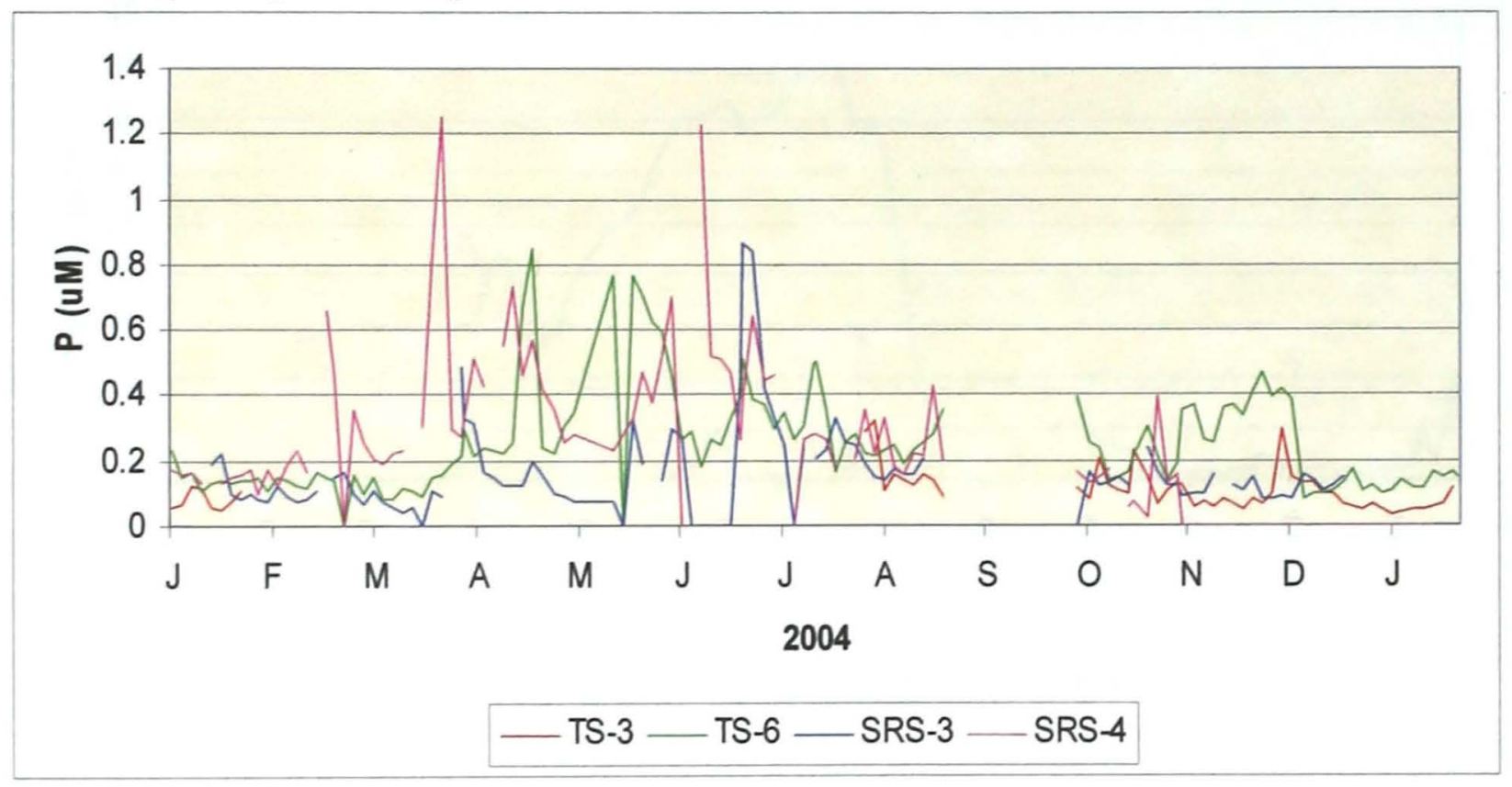


Figure 15: Average annual soil $P$ content for each sampling sites in the oligohaline ecotone. TS soils are generally characterized as marl, which have a much higher bulk density than SRS peat soils. If bulk density is incorporated (as P per unit volume of soil), the difference in $\mathrm{P}$ content between the two transects is much less dramatic.

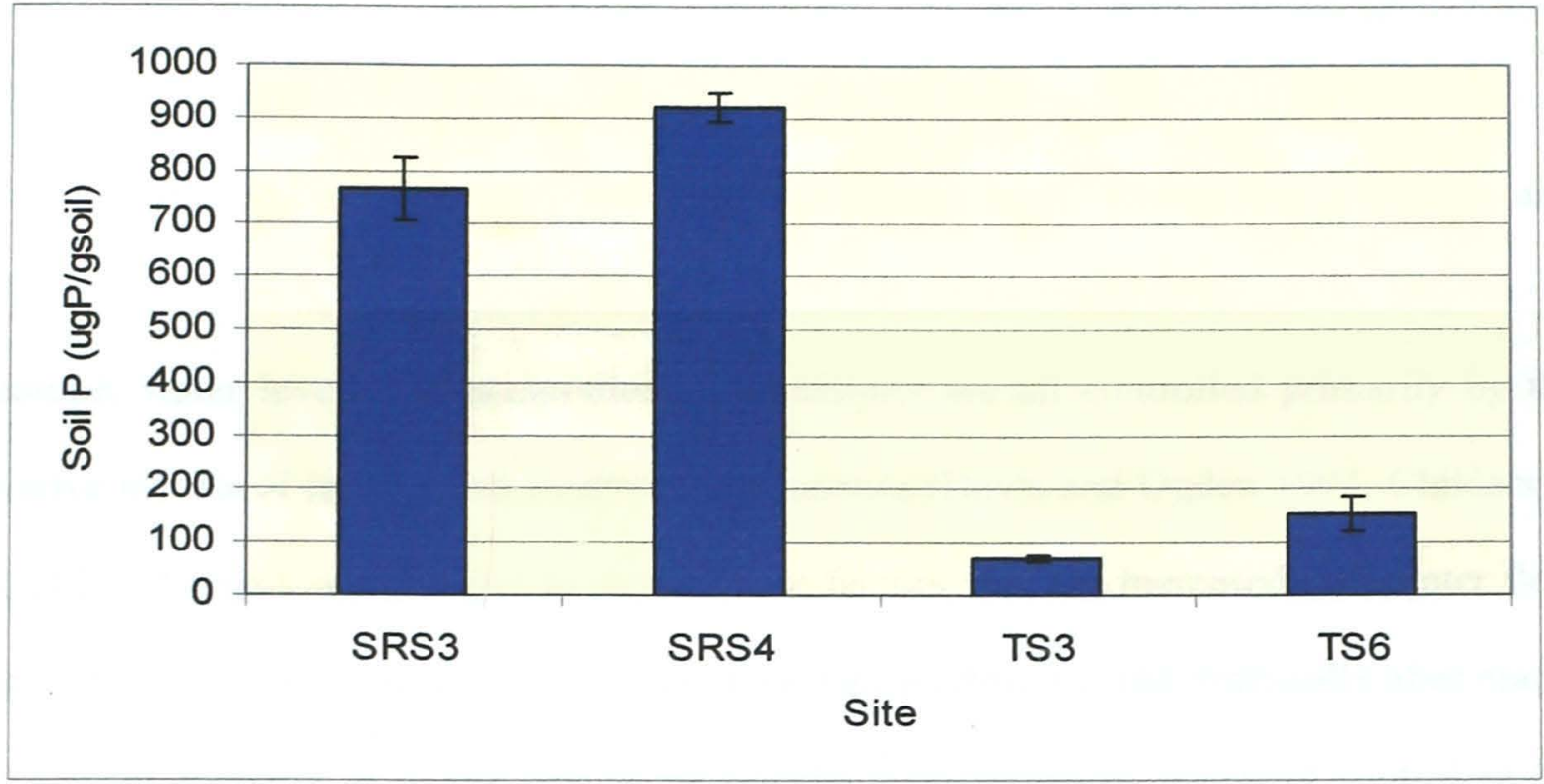

Figure 16: Water column salinity at each of the four ecotone sites. Breaks in the trend lines represent salinity readings of zero or result from a lack of water (marsh dry-downs). Each point is the mean of a three-day composite sample.

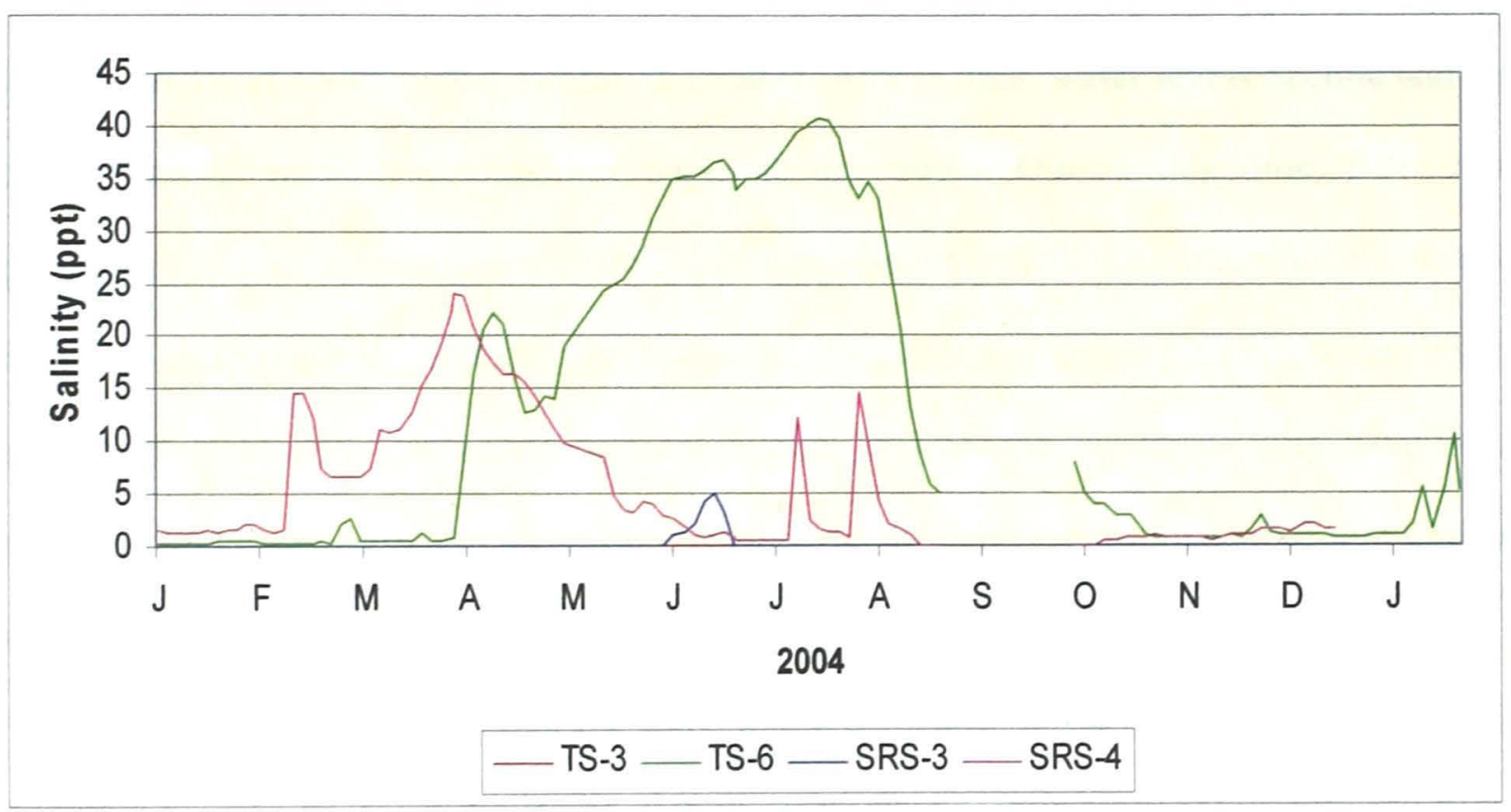


year than in TS: mid-July for TS-6 and late-March for SRS-4. TS- 6 exhibited particularly high salinity from June-August.

\section{DISCUSSION}

Hydrology and $\mathrm{P}$ availability control processes in the Everglades more than any other environmental factor (Steward \& Ornes 1983; Gunderson 1994). In the oligohaline ecotone, water level, P concentrations, and salinity are all controlled primarily by the relative effects of marine and freshwater influences (Davis and Ogden 1994, Childers et al. 2006). Large-scale changes to any of these factors, such as increased freshwater flow into the ecotone as a result of Everglades restoration efforts) could drastically alter marsh ecosystem function. It seems that in the oligohaline ecotone, hydroperiod controlled the observed patterns in BPP, while $\mathrm{P}$ availability had the most pronounced effect on belowground biomass trends.

At the onset of the dry season, water management reduces or stops canal inflows to both SRS and TS and local rainfall decreases. At this time, water levels decline and the oligohaline $C$. jamaicense marshes begin to dry down. During this time, BPP, root productivity, and rhizome productivity all increased to their maximum levels, which occurred in the late dry season. With the onset of the wet season, marsh water levels slowly rise and BPP decreased, suggesting that soil anoxia limitation may have been responsible. Often, as marsh water depths increase, wetland macrophytes become limited by hypoxia, and BPP decreases (Grace 1989; Morris et al. 2002; Sorrell et al. 2002).

Water management impacts were more apparent in TS, which dried down for durations varying from about $30-45$ (TS-6) to 90 days (TS-3). This timeframe would be 
sufficient for aerobic saturation of the marsh soils. Release from soil anoxia during this period may have caused the observed peak in BPP during the Dry-Wet Transition (MayJuly). SRS, on the other hand, is a larger watershed with greater local precipitation effects and canal inflows. Water management practices generally don't reduce canal inflows into the system until January or even February and marsh dry down events are far less frequent than in TS (roughly decadal compared with every year) (Childers et al. 2006). In SRS, the greatest BPP and root productivity also occurred in the Dry-Wet Transition period, which corresponded to the lowest measured water levels of the year. However the SRS marshes showed no long-duration dry-down event (a maximum of about 15 days at SRS-3), which may explain the lack of a substantial peak in BPP. Kludze and Delaune (1996) found an inverse relationship between root productivity and duration of inundation, supporting the observed variation in BPP and root productivity between the two sloughs.

Salinity was measurable much of the year in the estuarine marsh waters. Rhizome productivity in the oligohaline ecotone appeared to be driven more by salinity than hydroperiod as both the annual and 6-month BPP estimates were significantly lower at the estuarine sites. Salinity in the estuarine marshes exceeded the freshwater marshes, likely resulting in the decreased rhizome productivity observed. This claim may be supported by Whigham et al. (1989), who showed that rhizome growth in Typha angustifolia was reduced and restricted to a smaller growing area along a salinity gradient.

$\mathrm{P}$ content in SRS waters and soils exceeded those of TS because of the slough's direct connectivity to the relatively more $\mathrm{P}$ rich Gulf of Mexico waters (Chambers \& 
Pederson 2006; Childers et al. 2006). Total belowground biomass, root biomass, and rhizome biomass were all greater in the SRS transect, as a result of the relatively greater $P$ availability observed in the slough. Although these results seem to contradict resource allocation theory (Tilman 1985) as both aboveground and belowground biomass were greater in a more nutrient available area, they are in agreement with recent studies which found $C$. jamaicense belowground biomass to increase with nutrient enrichment in northeast SRS marshes (Daoust and Childers 2004), and in Water Conservation Area 2A (Miao and Sklar 1998). I suspect that because the ecotone is so oligotrophic, any additional $\mathrm{P}$ available in the marsh will be utilized by the plant for root or rhizome expansion or shoot elongation. The difference in soil $\mathrm{P}$ levels between the two transects becomes much smaller if soil bulk densities are considered (P per unit volume of soil instead of P per gram of soil). Tilman's resource allocation theory is applicable when nutrient availability between systems is great, and hence may not apply to comparisons between SRS and TS.

Marine water $\mathrm{P}$ content is relatively higher than the freshwater flowing into the oligohaline ecotone (Childers et al. 2006), therefore, due to their proximity to marine sources, the estuarine ecotone marshes exhibited higher water $\mathrm{P}$ concentrations than the freshwater marshes. A similar trend was found in the marsh soils of SRS, agreeing with the results of Chen \& Twilley (1999). Chambers \& Pederson (2006) found that soil P was constant between the ecotone sites in SRS, however per soil volume, higher P levels were found at the estuarine site. In TS, soil P was slightly greater at the estuarine site (Chambers \& Pederson 2006). The greater P availability in the estuarine marsh yielded increased root biomass, however total belowground biomass and rhizome biomass were 
similar between freshwater and estuarine sites. This was likely the result of salinity. Increased salinity adversely affects belowground biomass in freshwater marsh and salt marsh macrophytes (Howard and Mendelssohn 2000; Morris et al. 2002). Rhizome biomass has also been shown to decrease with increased salinity (Whigham et al 1989).

In the late stages of the dry season, freshwater inflows to the ecotone were low to non-existent and the impact of the marine $\mathrm{P}$ was more apparent. The ecotone marsh waters experienced the highest $\mathrm{P}$ concentrations of the year during this time frame, agreeing with the findings of Childers et al. (2006). This could support the idea that $P$ availability drove the increased BPP observed in the late dry season. However, annual BPP and root productivity showed no significant spatial variability in the ecotone (SRS = TS and freshwater = estuarine) and thus no nutrient effects. These results correspond to the literature which has shown that nutrient addition had no effect on belowground productivity in a temperate freshwater marsh (Bayley et al. 1985), and that there is no clear relation between $C$. jamaicense growth rate and $\mathrm{P}$ availability (Lorenzen et al. 2001). If nutrient availability was driving BPP, I would expect the roots found in SRS marshes to have a relatively higher $\mathrm{P}$ content compared to roots from TS as a result of the increased $\mathrm{P}$ available in the transect. Yet, C. jamaicense root $\mathrm{P}$ content was less in SRS. These results are supported by Shaver and Melillo (1984), who found that when P availability increases, the proportion of available $\mathrm{P}$ taken up by marsh plants decreases. Soil P levels display low variability over long time scales (Noe \& Childers 2003), therefore, one soil $\mathrm{P}$ measurement was sufficient to capture the nutrient concentration at each site. As a result, I was unable to test whether soil $\mathrm{P}$ levels mimicked the observed seasonal patterns in water column P or controlled seasonal patterns in BPP. 
Annual BPP estimates from this study are consistent with those published for freshwater marshes (Brinson et al. 1981; Birch \& Cooley 1982; Symbula and Day 1988; Chimner \& Ewel 2005), and with those found in a C. Jamaicense marsh in northern SRS (Daoust \& Childers 2004), but generally lower than those published for coastal salt marshes (Valieta et al. 1976; Schubauer \& Hopkinson 1984). This latter result is expected as salt marshes generally have greater nutrient availability than oligotrophic Everglades' marshes, and species occurring in oligotrophic systems have lower production per unit $\mathrm{P}$ than species common to more nutrient rich systems (Chapin 1980). Comparisons between the BPP results of this study and others in the literature must be interpreted with caution, as a number of different methodologies are currently being used to estimate BPP (Vogt et al. 1998). As an example of the variability among sampling techniques, BPP estimates in undisturbed Georgia coastal marsh ecosystems have varied by more than $2500 \mathrm{~g} / \mathrm{m}^{2} / \mathrm{yr}$ under various sampling methodologies (Schubauer \& Hopkinson 1984). The ingrowth core method was selected for this experiment because it is widely used, allows a clear idea of the time period in which root growth occurs (Neill 1992), and is very effective in wet tropical ecosystems (Vogt et al. 1998). However, the literature suggests that the ingrowth core method may overestimate BPP in some systems (Neill 1992; Vogt et al. 1998; Hendricks et al. 2006). For this reason, this study focused more on understanding the observed BPP trends in the oligohaline ecotone marsh and less on how BPP of this system compares to others.

Root productivity accounted for approximately $72 \%$ of total annual BPP. This makes sense because a plant must invest energy to obtain nutrients (root expansion) before it can store the nutrients in the rhizomes. This is better exemplified by the 3-month 
and 6-month productivity data which showed a time lag between root and rhizome productivity. Roots accounted for (on average) $92 \%$ and $86 \%$ of BPP in the respective 3month and 6-month "incubation periods". Hence, the greater the duration between sampling events, the closer to "one" the root:rhizome BPP ratio will become. If productivity estimates are derived from biomass samples, which measure accumulated material over a long time period, a root:rhizome BPP ratio of about "one" would be expected. Gallagher et al. (1984) found a similar ratio in Spartina alterniflora using sequential biomass cores.

A majority of the root productivity occurred in the top $10 \mathrm{~cm}$ of soil, similar to the findings summarized by Good et al. (1981). Oxygen becomes less available further down the soil column and Kludze and Delaune (1996) showed that reduced oxygen availability reduced root productivity. Chambers and Pederson (2006) found that $\mathrm{P}$ availability was highest at the soil surface and decreased exponentially with depth at these sites, which could also explain the high amount of root growth near the top of the soil column. Almost all rhizome productivity occurred less than $10 \mathrm{~cm}$ below the soil surface. Rhizomes are horizontal stems and the primary nutrient storage structures in the plant (Gallagher et al. (1984). In terms of energy expenditure of the plant, rhizomes are best located just below the soil surface so new meristems can easily sprout from the rhizome nodes. Similarly, because rhizomes do not actively uptake nutrients or water, resources are better allocated to roots which penetrate deep into the soil column to obtain these limiting agents.

Total belowground biomass estimates from this study are consistent with those from previous research on salt marsh and freshwater marsh ecosystems throughout the world (Shafer and Streever 2000; Van Wijnen and Bakker 2000; Miller and Zedler 2003; 
Turner et al. 2004). Closer to home, two previous Everglades marsh studies found $C$. jamaicense belowground biomass values either similar to (Daoust and Childers 2004) or substantially lower (Miao and Sklar 1998) than the results of this study. Miao and Sklar (1998) sampled belowground biomass along a nutrient transect in Water Conservation Area $2 \mathrm{~A}$, an area in the northern Everglades with relatively deeper water levels, longer water retention times, and considerably higher soil P content (Davis \& Ogden 1994). The relatively longer hydroperiod and $\mathrm{P}$ availability in their study sites could result in decreased BPP (as the seasonal BPP results suggest) and over the course of time cause relatively lower belowground biomass.

On average, $C$. jamaicense allocated slightly more biomass to rhizomes than to root structures (53\% to $47 \%$ ). Saunders et al. (2005) showed a similar rhizome to root biomass allocation ratio in a salt marsh, however Miao and Sklar (1998) again provided a substantially lower result in the northern Everglades. A simple explanation for this discrepancy may be that shoot bases and rhizomes were classified together in this experiment, yet were differentiated in the previous study.

The most unexpected trend in this study was the seasonal variation in total belowground biomass. No variation between the sampling events was expected. The basis of this hypothesis derived from oligohaline Everglades marshes being peat building systems, where belowground biomass accumulation rates exceed decomposition rates, creating a dense layer of living and partially decomposed root and rhizomes (Brinson et al. 1981). Any increase in annual belowground biomass (or BPP) would contribute little to the pool of belowground biomass already present. If anything, a slight increase in belowground biomass should have been observed in the July sampling based on the 
increased productivity that occurred in the dry season (as described above). The biomass data, however, did not show this trend. Mean total belowground biomass and rhizome biomass were significantly less in the July sampling event. Root biomass estimates were statistically similar between sampling events, yet the July sample yielded less biomass at all sites except TS-3. January rhizome biomass was, on average, about two times higher than in the July sampling across all sites, driving the trends seen for total belowground biomass. This cannot be explained by the rhizome BPP data. Even under periods of marsh dry down, it is unlikely that decomposition could have such an impact as to decrease rhizome biomass by half. The lack of relation between BPP and belowground biomass shows that further research is needed, particularly involving root mortality and decomposition, to understand the controls on belowground processes in oligohaline marshes.

Aboveground biomass estimates from this experiment were lower than previous studies on C. jamaicense marsh aboveground biomass (Newman et al. 1996; Miao and Sklar 1998; Daoust and Childers 2004). Subsequently, the A:B biomass ratios were also comparatively lower than previous studies (Miao and Sklar 1998; Lorenzen et al. 2001; Daoust and Childers 2004). P availability was relatively higher at the experimental sites of these comparative studies, which could translate to more aboveground biomass (Chapin 1980). This greater P most likely explains the relatively greater aboveground biomass and $\mathrm{A}: \mathrm{B}$ biomass ratios. My aboveground estimates were consistent with mean long-term estimates at TS-3, TS-6 (Childers et al. 2006), and SRS-3 (Childers unpub.). Both aboveground biomass and $\mathrm{A}: \mathrm{B}$ biomass ratios seemed to increase with $\mathrm{P}$ availability as each were significantly greater in SRS. However, previous studies have found no clear 
relationships between $C$. jamaicense $\mathrm{A}: \mathrm{B}$ biomass ratio and $\mathrm{P}$ availability (Miao and Sklar 1998; Lorenzen et al. 2001) nor oxygen availability (Lorenzen et al. 2001). It seems that further research is again needed in order to better understand the impacts of $P$ availability and oxygen on biomass allocation.

On average, root turnover estimates from this study more than doubled the rates reported for other tropical wetlands (Gill and Jackson 2000). Root turnover at SRS-4 was a quarter of that measured for the other sites. SRS-4 was the only site with continuous inundation, likely maintaining anoxic soil conditions throughout the year. Decomposition rates tend to be slower in anaerobic soils (Brinson et al. 1981), which would increase root longevity and thus biomass. This could explain why SRS-4 biomass exceeded all other sites, resulting in the substantially lower root turnover estimate. If SRS-4 is not taken into account, root turnover rates average just under a year. This mean is still about $50 \%$ higher than other tropical wetland turnover rates (Gill and Jackson 2000). A possible explanation for the greater turnover in this study could be an underestimation of root biomass caused by inherent problems with the live root separation technique (categorizing too few partially-living roots as live biomass). An underestimation of root biomass, rather than an overestimation of root productivity, is suggested because the classification of living versus dead roots was much more difficult in the standing stock soil cores. It should be noted that considerable variability exists in root turnover estimates, based on inherent faults in the methodology and a lack of methodological concurrence in the literature. Applying different root turnover assessment methods to the same site in the same year has resulted in turnover rates varying by one order of 
magnitude (Gill and Jackson 2000). Not until the methods are refined will turnover comparisons between systems or biomes be meaningful.

Root turnover rates in SRS were relatively lower than those of TS. Previous research has found root turnover rates to be highest where nutrient availability is greatest (Nadelhoffer et al. 1985; Bouma et al. 2002; West et al. 2004), which contrasts the observed trend. Bouma et al. (2002) demonstrated greater turnover in salt marsh macrophytes occurring in reduced hydroperiod areas, which could support the greater turnover observed in TS. Rhizome turnover trends showed relatively lower rates in estuarine marshes, which could potentially be caused by salinity. Like root turnover, substantially less rhizome turnover was found at SRS-4. Unfortunately, the literature lacks studies containing rhizome turnover data, thus, no comparisons to other systems could be made. Due to this study's slightly higher root turnover rates compared to the literature and the extremely low mean turnover estimated at SRS-4, the accuracy of these turnover rates can be questioned. For this reason, the turnover estimates of this study should be used as a basis of comparison for future work, and not held as fact. Research on belowground decomposition is crucial to advancing our understanding of belowground ecosystem processes and not until this research is performed will an adequate estimation of turnover be available for oligohaline marshes.

The two most prevalent theories regarding nutrient controls on net primary productivity (NPP) and biomass allocation in terrestrial systems are: 1) NPP increases with greater nutrient availability accompanied by an increase in the proportion of NPP allocated to aboveground structures, and decrease in the proportion of NPP allocated to roots; and 2) NPP increases with greater nutrient availability, but the proportion of NPP 
allocated to aboveground structures and roots remains constant (Hendricks et al. 2006). Although this experiment showed constant root productivity in response to increased nutrient availability, the relationship between nutrient availability and total productivity (aboveground + belowground) in Everglades oligohaline marshes is currently unclear. Future research assessing both productivity and turnover along nutrient gradients or between SRS and TS would provide further insight as to how $C$. jamaicense marshes fit into the theories described above. However, nutrient availability may not be the primary driver of wetland NPP.

In this experiment, nutrient availability had no clear affect on BPP. It seems that in studies at scales larger than individual plants, there is no consensus as to whether root productivity increases or decreases with increased nutrient availability (Nadelhoffer, 2000). BPP did show a negative response to water level and hydroperiod, agreeing with the conclusions of Childers et al. (2006), who found a decrease in C. jamaicense marsh aboveground net primary productivity with water level and hydroperiod. The coupling of both reduced aboveground and belowground productivity with increased water level, as a result of Everglades Restoration efforts, could result in substantial changes to a landscape that has already changed considerably in the last $50-100$ years. Reinforcing the notion of Childers et al. (2006) that reduced C. jamaicense productivity, in response to increased hydroperiod and water level, will lead to a reduction in C. jamaicense abundance, and replacement by deeper water-tolerant species (such as Eleocharis spp. and Nymphaea odorata), in areas impacted most by Everglades restoration. In the oligohaline ecotone, not only would Eleocharis and Nymphaea become more abundant, but mangroves may also replace the $C$. jamaicense under deeper and longer hydrologic conditions. 
Sea level rise will also act to create deeper water levels and longer hydroperiods in oligohaline $C$. jamaicense marshes, though at a much slower rate. Decreased accretion rates, and the subsequent lowering of the peat elevation, will be a direct result of reduced BPP caused by increased water and salinity inputs associated with sea level rise (Morris et al. 2002). Over the past fifty years, reduced freshwater levels in combination with sea level rise has allowed saltwater to intrude further into the Everglades, creating a landward expansion of the mangrove zone (Ross et al. 2000; Gaiser et al. 2006) and a spatial decline in freshwater marsh ecosystems. I suspect that Everglades restoration will counteract sea level rise by shifting the oligohaline ecotone seaward, however, $C$. jamaicense will become less abundant as it will be out-competed by deeper water and/or more salt-tolerant species.

\section{Conclusion}

Belowground biomass and BPP in C. jamaicense marshes of the oligohaline ecotone may be controlled by different environmental drivers. While water level and hydroperiod were shown to negatively affect $C$. jamaicense BPP, these drivers had no clear effect on belowground biomass or biomass allocation. The literature suggests that belowground biomass is driven by the availability of the limiting nutrient, increasing when nutrient limitation increases, as per resource allocation theory (Tilman 1985). In contrast to this theory, the results of this study showed that both belowground biomass and $\mathrm{A}: \mathrm{B}$ biomass ratios increased with greater nutrient availability, suggesting that oligotrophic systems are at the low end of the nutrient availability range necessary for resource allocation theory to be applicable. However, the interactions and influence of 
hydrology and salinity on belowground biomass need to be better understood in the system.

Further research is needed in order to adequately characterize belowground biomass and $\mathrm{BPP}$ in the C. jamaicense marshes of the oligohaline ecotone. Incorporating alternative methods, such as minirhizotrons, nitrogen budget, and carbon budget, may provide a more accurate estimation of belowground biomass and BPP. Root mortality and decomposition were not incorporated into this study, yet are crucial to establishing accurate BPP estimates (Vogt et al. 1998; Hendricks et al. 2006). Future research needs to focus on understanding these processes, particularly in response to nutrient availability and hydroperiod. Only then will we have a sufficient comprehension of the patterns and controls of BPP and belowground biomass allocation and, hence the structure and function of marsh ecosystems. 


\section{LIST OF REFERENCES}

Bayley, S.E., Zoltek, Jr., J., Hermann, A.J., Dolan, T.J., and Tortora, L. 1985. Experimental Manipulation of Nutrients and Water in a Freshwater Marsh: Effects of Biomass, Decomposition, and Nutrient Accumulation. Limnology and Oceanography, 30, 500-512.

Birch, J.B. and Cooley, J.L., 1982 Production and standing crop patterns of giant cutgrass (Zizaniopsis miliacea) in a freshwater tidal marsh. Oecologia. 52, 230-235.

Bloomfield, J., Vogt, K. and Vogt, D., 1993. Decay rate and substrate quality of fine roots and foliage of two tropical tree species in the Luquillo Experimental Forest, Puerto Rico. Plant and Soil, 150, 233-245.

Bouma, T.J., Hengst, K., Koutstaal, B.P., and van Soelen, J., 2002. Estimating root lifespan of two grasses at contrasting elevation in a salt marsh by applying vitality staining on roots from ingrowth cores. Plant Ecology, 165, 235-245.

Brinson, M.M., Lugo, A.E., and Brown, S., 1981. Primary Productivity, Decomposition and Consumer Activity in Freshwater Wetlands. Annual Review of Ecology and Systematics, 12, 123-161.

Chabbi A., Mckee, K.L., and Mendelssohn, I.A., 2000. Fate of oxygen losses from Typha domingensis (Typhaceae) and Cladium jamaicense (Cyperaceae) and consequences for root metabolism. American Journal of Botany, 87, 1081-1090.

Chambers, R.M. and Pederson, K.A., 2006. Variation in soil phosphorus, sulfur, and iron pools among south Florida wetlands. Hydrobiologia, 569, 63-70.

Chapin, F.S.I., 1980. The mineral nutrition of wild plants. Review of Ecology and Systematics, 11, 233-260.

Chen, R. and Twilley, R.R., 1999. A simulation model of organic matter and nutrient accumulation in mangrove wetland soils. Biogeochemistry, 44, 93-118.

Childers, D.L., Doren, R.F., Noe, G.B., Rugge, M., and Scinto L.J., 2003. Decadal change in vegetation and soil phosphorus patterns across the Everglades landscape. Journal of Environmental Quality, 32, 344-362.

Childers, D.L., Boyer, J.N, Davis, S.E., Madden, C.J, Rudnick, D.T., and Sklar, F.H 2006. Relating precipitation and water management to nutrient concentration patterns the oligotrophic "upside down" estuaries of the Florida Everglades. Limnology ar Oceanography, 51, 602-616. 
Childers, D.L., Iwaniec, D., Rondeau, D., Rubio, G.A., Verdon, E., and Madden, C.J., 2006. Responses of sawgrass and spikerush to variation in hydrologic drivers and salinity in southern Everglades marshes. Hydrobiologia, 569, 273-292.

Chimner, R.A. and Ewel, K.C., 2005. A Tropical Freshwater Wetland: II. Production, Decomposition, and Peat Formation. Wetlands Ecology and Management, 13, 671-684.

Coronado-Molina, C., Day, J.W., Reyes, E., and Perez, B.C., 2004. Standing crop and aboveground partition in a dwarf mangrove forest in Taylor River Slough, Florida. Wetlands Ecology and Management, 12, 157-164.

Daoust, R.J. and Childers, D.L., 1999. Controls on emergent macrophyte composition, abundance, and productivity in freshwater Everglades wetland communities. Wetlands, $19,262-275$.

Daoust, R.J. and Childers, D.L., 2004. Ecological effects of low-level phosphorus additions on two plant communities in a neotropical freshwater wetland ecosystem. Oecologia, 141, 672-686.

Davis, S.M., 1989. Sawgrass and cattail production in relation to nutrient supply in the Everglades. In: Sharitz, R.R. and Gibbons, J.W. (eds) Freshwater Wetlands and Wildlife. DOE Symposium Series No. 61, Oak Ridge, TN, 325-341.

Davis, S. and Ogden, J., 1994. Everglades: The ecosystem and it restoration. St. Lucie Press, Delray Beach, FL.

Davis, S.E., Cable, J.E., Childers, D.L., Coronado-Molina, C., Day, J.W., Hittle, C.D., Madden, C.J., Rudnick, D., Reyes, E., and Sklar, F., 2004. Importance of episodic storm events in controlling ecosystem structure and function in a Gulf Coast estuary. Journal of Coastal Research, 20, 1198-1208.

Florida Coastal Everglades LTER. Florida Coastal Everglades LTER Website. March, 2003.

Fourqurean, J., Jones, R. and Zieman, J., 1993. Processes influencing water column nutrient characteristics and phosphorous limitation of phytoplankton biomass in Florida Bay, FL, USA: influences from spatial distributions. Estuarine, Coastal, and Shelf Science, 36, 295-314.

Gaiser, E.G., Zafiris, A., Ruiz, P.L., Tobias, F.A.C., and Ross, M.S., 2006. Tracking rates of ecotone migration due to salt-water encroachment using fossil mollusks in coastal South Florida. Hydrobiologia, 569, 237-257.

Gallagher, J.L., Wolf, P.L., and Pfeiffer, W.J., 1984. Rhizome and root growth rates and cycles in protein and carbohydrate concentrations in Georgia Spartina alternaflora Loisel. plants. American Journal of Botany, 71, 165-169. 
Gill, R.A. and R. B. Jackson, R.B., 2000. Global patterns of root turnover for terrestrial ecosystems. New Phytologist, 147, 13-31.

Gleeson, S.K. and Tilman, D., 1992. Plant allocation and the multiple limitation hypothesis. The American Naturalist, 139, 1322-1343.

Good, R.E., Good, N.F., and Frasco, B.R., 1981. Review of Primary Production and Decomposition Dynamics of the Belowground Marsh Component. Proceedings of the Sixth Biennial International Estuarine Research Conference, 139-157.

Gosz, J.R. and Sharpe, P.J.H., 1989, Broad-scale concepts for interactions of climate topography and biota at biome transitions. Landscape Ecology, 3, 229-243.

Gosz, J.R. 1993. Ecotone Hierarchies. Ecological Applications, 3, 369-376.

Grace, J.B., 1989. Effects of water depth on Typha latifolia and Typha domingensis. American Journal of Botany, 76, 762-768.

Grier, C., Vogt, K., Keyes, M. and Edmunds, R., 1981. Biomass distribution and aboveand below-ground production in young and mature Abies amabilis zone ecosystems of the Washington Cascades. Canadian Journal of Forest Resources, 11, 155-167.

Gunderson, L., 1994. Vegetation of the Everglades: Determinants of Community Composition. Everglades: The Ecosystem and Its Restoration (Davis, S and Ogden, J), pp. 323-340. St. Lucie Press, Delray Beach, FL.

Hendricks, J.J., Hendrick, R.L., Wilson, C.A., Mitchell, R.A., Pecot, S.D., and Guo, D., 2006. Assessing the patterns and controls of fine root dynamics: an empirical test and methodological review. Journal of Ecology, 94, 40-57.

Hertel, D. and Leuschner, C., 2002. A comparison of four different fine root production estimates with ecosystem carbon balance data in fagus-quercus mixed forest. Plant and Soil, 239, 237-251.

Howard, R.J. and Mendelssohn, I.A., 2000. Structure and composition of oligohaline marsh plant communities exposed to salinity pulses. Aquatic Botany, 68, 143-164.

Jones, R., Lockaby, B. and Somers, G., 1996. Effects of microtopography and disturbance on fine-root dynamics in wetland forests of low-order stream floodplains. American Midland Naturalist, 136, 57-71.

Kludze, H.K. and DeLaune, R.D., 1996. Soil redox intensity effects on oxygen exchange and growth of cattail and sawgrass. Soil Science Society of America Journal, 60, 616621 . 
Knapp, A.K., Briggs, J.M., and Childers, D.L., 2005. Estimating aboveground net primary production in grassland and herbaceous dominated systems . In T.J. Fahey and A.K. Knapp, (eds.) Principles and Standards for Measuring Net Primary Production in Long-term Ecological Studies. Oxford University Press.

Loneragan, J.F. and Asher, C.J., 1967. Response of plants to phosphate concentration in the solution culture. II. Rate of phosphate absorption and its relation to growth. Soil Science, 103, 311-318.

Lorenzen, B., Brix, H., Mendelssohn, I.A., McKee, K.L., and Miao, S.L., 2001. Growth, biomass allocation and nutrient use efficiency in Cladium jamaicense and Typha domingensis as affected by $\mathrm{P}$ and oxygen availability. Aquatic Botany, 70, 117-133.

Miao, S.L. and Sklar, F.H., 1998. Biomass and nutrient allocation of sawgrass and cattail along a nutrient gradient in the Florida Everglades. Wetlands Ecology and Management, $5,245-263$.

Miller, R.C. and Zedler, J.B., 2003. Response of native and invasive wetlands plants to hydroperiod and water depth. Plant Ecology, 167, 57-69.

Mitsch, W. and Gosselink, J., 2000. Wetlands. John Wiley \& Sons, Inc., New York.

Morris, J.T., Sundareshwar, P.V., Nietch, C.T., Kjerfve, B., and Cahoon, D.R., 2002. Responses of coastal wetlands to rising sea level. Ecology, 83, 2869-2877.

Nadelhoffer, K., 2000. The potential effects of nitrogen deposition on fine-root production in forest ecosystems. New Phytologist, 147, 131-139.

Nadelhoffer, K., Aber, J. and Melillo, J., 1985. Fine roots, net primary production, and soil nitrogen availability: a new hypothesis. Ecology, 66, 1377-1390.

Nadelhoffer, K. and Raich, J., 1992. Fine root production estimates and belowground carbon allocation in forest ecosystems. Ecology, 73, 1139-1147.

Naiman, R.J., Decamps, J., and Johnston, C.A., 1988. The potential importance of boundaries to fluvial ecosystems. Journal of the North American Benthological Society, 7, 289-306.

Neill, C., 1992. Comparison of soil coring and ingrowth methods for measuring belowground production. Ecology, 73, 1918-1921.

Neilson, R., 1993. Transient ecotone response to climatic change: some conceptual and modelling approaches. Ecological Applications, 3, 385-395.

Newman, S., Grace, J.B., and Koebel, J.W., 1996. Effects of nutrients and hydroperiod on Typha, Cladium and Eleocharis: Implications of Everglades restoration. Ecological Applications, 6, 774-783. 
Noe, G.B. and Childers, D.L., (In Press). Phosphorus budgets in Everglades wetland ecosystems: The effects of hydrology and nutrient enrichment. Wetlands Ecology and Management.

O'Neill, R.V., Johnson, A.R., and King, A.W., 1989. A hierarchical framework for the analysis of scale. Landscape Ecology, 3, 193-205.

Ricklefs, R. and Miller, G., 2000. Ecology. W.H. Freeman and Co., New York.

Robertson, A.I. and Dixon, P., 1993. Separating live and dead fine roots using colloidal silica: an example from mangrove roots. Plant and Soil, 157, 151-154.

Ross, M.S., Meeder, J.F., Sah, J.P., Ruiz, P.L., and Telesnicki, G.J., 2000. The southeast saline Everglades revisited: 50 years of coastal vegetation change. Journal of Vegetation Science, 11, 101-112.

Saunders, C.J., Megonigal, J.P. and Reynolds, J.F., 2005. Comparison of belowground biomass in $\mathrm{C}_{3}$ - and $\mathrm{C}_{4}$-dominated mixed communities in a Chesapeake Bay brackish marsh. Plant and Soil, 00, 1-18.

Rubio, G.A. and Childers, D.L., 2006 (In Press). Controls of herbaceous litter decomposition in the estuarine ecotones of the Florida Everglades. Estuaries and Coasts, 29(2).

Schubauer, J.P. and Hopkinson, C.S., 1984. Above- and belowground macrophyte production and turnover in a coastal marsh ecosystem, Georgia. Limnology and Oceanography, 29, 1052-1065.

Scurlock, J., Johnson, K. and Olson, R., 2002. Estimating net primary productivity from grassland biomass dynamics measurements. Global Change Biology, 8, 736-753.

Shafer, D.J. and Streever, W.J., 2000. A comparison of 28 natural and dredged material salt marshes in Texas with an emphasis on geomorphological variables. Wetlands Ecology and Management, 8, 353-366.

Sharp, L. and Solorzano, J.H., 1980. Determination of total dissolved phosphorus and particulate phosphorus in natural waters. Limnology and Oceanography, 25, 754-758.

Sharp, J., Pennock, J., Church, T., Tramontano, J. and Cifuentes, L., 1984. The estuarine interactions of nutrients, organics, and metals: A case study in the Delaware Estuary. The Estuary as a Filter (Kennedy), pp. 241-258. Academic Press.

Shaver, G.R. and Melillo, J.M., 1984. Nutrient budgets of marsh plants: Efficiency concepts and relation to availability. Ecology, 65, 1491-1510. 
Sorrell, B.K., Tanner, C.C., and Sukias, J.P.S., 2002. Effects of water depth and substrate on growth and morphology of Eleocharis sphacelata: Implications for culm support and internal gas transport. Aquatic Botany, 73, 93-106.

Steward, K.K. and Ornes, W.H., 1983. Mineral nutrition of sawgrass (Cladium jamaicense Crantz) in relation to nutrient supply. Aquatic Botany, 16, 349-359.

Symbula, M. and Day, Jr., F.P., 1988. Evaluation of two methods for estimating belowground production in a freshwater swamp forest. The American Midlands Naturalist, 120, 405-415.

Tilman, D., 1985. The resource-ratio hypothesis of plant succession. The American Naturalist, 125, 827-852.

Turner, R.E., Swenson, E.M., Milan, C.S., Lee, J.M., and Oswald, T.A., 2004. Belowground biomass in healthy and impaired salt marshes. Ecological Research, 19, 29-35.

Valiela, I., Teal, J.M., and Persson, N.Y., 1976. Production and dynamics of experimentally enriched salt marsh vegetation: Belowground biomass. Limnology and Oceanography, 21, 245-252.

Van Wijnen, H.J. and Bakker, J.P., 2000. Annual nitrogen budget of a temperate coastal barrier salt-marsh system along a productivity gradient at low and high marsh elevation. Perspectives in Plant Ecology, Evolution and Systematics, 3, 128-141.

Vogt, K. and Persson, H., 1991. Root methods. Techniques and approaches in forest tree ecophysiology (Lassoie, J and Hinckley, T), pp. 477-502. CRC Press, Boca Raton, FL.

Vogt, K., Vogt, D. and Bloomfield, J., 1998. Analysis of some direct and indirect methods for estimating root biomass and production of forests at an ecosystem level. Plant and Soil, 200, 71-89.

West, J.B., Espelata, J.F., and Donovan, L.A., 2004. Fine root production and turnover across a complex edaphic gradient of a Pinus palustis-Aristida stricta savanna ecosystem. Forest Ecology and Management, 189, 397-406.

Whigham, D.F., Jordan, T.E., and Miklas, J., 1989. Biomass and resource allocation of Typha angustifolia L. (Typhaceae): The effect of within and between year variations in salinity. Bulletin of the Torrey Botanical Club, 116, 364-370.

Zar, J.H., 1996. Biostatistical Analysis $3^{\text {rd }}$ Ed., Prentice Hall, New Jersey, USA. 